\title{
5 \\ Russian Energy Firms in the Eastern Market
}

\author{
Keun-Wook Paik
}

Since early 2014, when the Crimean Peninsula was annexed by the Russian Federation and Western sanctions against Russia began to affect its global oil and gas export boundaries, ${ }^{1}$ Moscow has had no choice but to prioritise its Asia-Pacific strategy. Russia had laid solid groundwork for its entry into the Asian oil and gas market with completion of the East Siberia - Pacific Ocean (ESPO) oil pipeline in 2009. In 2018, Russia became China's biggest supplier of crude oil, delivering $71.5 \mathrm{mt}$. In December 2019, the long waited Power of Siberia (POS) 1 gas started to flow; by 2025 , it will reach to its full capacity of $38 \mathrm{bcm} / \mathrm{y}$. Russia's independent gas producer, Novatek, transformed the country into an Arctic onshore gas-based liquefied natural gas (LNG) supplier in December 2017 and aims to commission $19.8 \mathrm{mt} / \mathrm{y}$ of Arctic LNG by $2023 .^{2}$ If the longdelayed Altai gas export to China is materialised during the 2020s,

\footnotetext{
1 'Crimea Profile', BBC News, 17 January 2018, www.bbc.co.uk/news/world-europe-18287223; Andrew Chatzky, 'Have Sanctions on Russia Changed Putin's Calculus?', Council on Foreign Relations, 2 May 2019, www.cfr.org/article/have-sanctions-russia-changed-putins-calculus.

2 For background on Sino-Russian oil and gas cooperation during 2014-17, see Keun-Wook Paik, 'Sino-Russian Gas and Oil Cooperation: Entering into an Era of Strategic Partnership', OIES Paper WPM 59, April 2015, www.oxfordenergy.org/wpcms/wp-content/uploads/2015/04/WPM-59.pdf; Keun-Wook Paik, 'Sino-Russian Oil and Gas Cooperation: Where It Stands and How Far Can It Expand?', Geopolitics of Energy 38, no. 8 (August 2016): 2-10; Keun-Wook Paik, 'Sino-Russian LNG Trade Perspectives', in A North Pacific Dialogue on Arctic 2030: Pathways to the Future, ed. Robert W. Corell et al. (KMI and East-West Centre, 2018), 293-304.
} 
it will guarantee Russia's successful entry into the Asia-Pacific oil and gas market, and Sino-Russian oil and gas cooperation will play a pivotal role in transforming Russia in the 2020s.

This chapter evaluates the performance of Russia's two state-owned flagship oil and gas entities, Rosneft and Gazprom, and the country's biggest independent gas producer, Novatek, with a view to better understanding the achievements and prospects of Sino-Russian oil and gas cooperation.

\section{Rosneft: Sweet Success in Oil but Unfulfilled Wishes in Gas}

Together with Transneft, Rosneft was the driving force behind the ESPO oil pipeline. Completion of the first stage of the pipeline in December 2009 opened the era of Russia's supply of crude oil to the Asian market. ${ }^{3}$ Transneft sent $38.3 \mathrm{mt}$ of crude to China in 2018, up 44.5 per cent year on year, according to data by the Central Dispatching Unit (CDU), the statistics arm of Russia's energy ministry. Crude loadings from Kozmino amounted to $30.386 \mathrm{mt}$ in 2019 , down 4.2 per cent year on year, according to the CDU data. ${ }^{4}$

As shown in Figure 5.1, in 2018, China's total crude imports were $461.9 \mathrm{mt}$, of which Russia provided 15 per cent $(71.49 \mathrm{mt})$, followed by Saudi Arabia (12 per cent or $56.73 \mathrm{mt}$ ), Iraq and Angola (10 per cent each), Brazil and Oman (7 per cent each), and Iran (6 per cent).

3 'Projects Underway', Transneft, accessed 22 August 2020, en.transneft.ru/about/projects/current/.

4 Nadia Rodova, 'Transneft Sees Fast Growth in Arctic, E Siberian Crude Pipeline Flows', Platts S\&P Global, 5 April 2019, www.spglobal.com/platts/en/market-insights/latest-news/oil/ 040519-transneft-sees-fast-growth-in-arctic-e-siberian-crude-pipeline-flows; 'Eastern Siberia-Pacific Ocean Oil Pipeline', Wikipedia, last modified 19 September 2019, en.wikipedia.org/wiki/Eastern_ Siberia\%E2\%80\%93Pacific_Ocean_oil_pipeline; 'Russia’s Rosneft Aims for \$500bn Worth of Energy Deals with China', RT, 29 November 2018, www.rt.com/business/445140-rosneft-china-energycooperation/. But the record of 2019 may not be as good as that of 2018. See, Avantika Ramesh, 'Russia’s Feb ESPO Blend Crude Oil Exports Down 10 Per Cent on Month', Platts S\&P Global, 4 January 2019, www.spglobal.com/platts/en/market-insights/latest-news/oil/010419-russias-feb-espoblend-crude-oil-exports-down-10-on-month. 


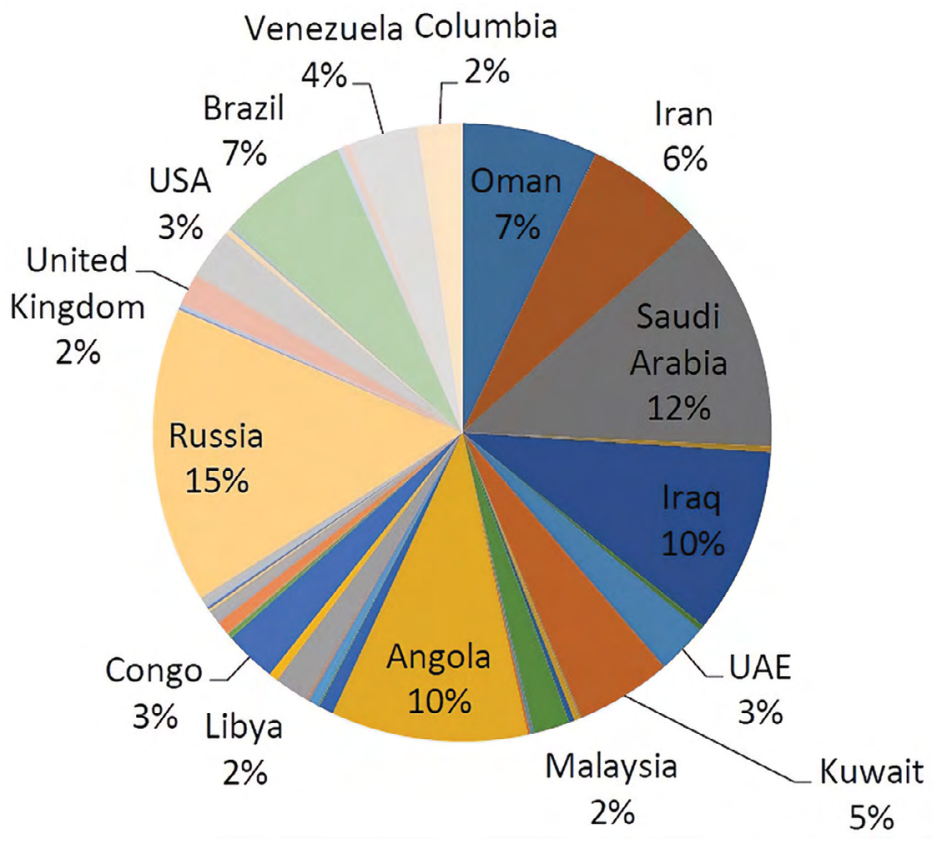

Figure 5.1: China's crude oil imports by country.

Source: China OGP, 1 February 2019, 6.

According to China OGP, an oil industry newsletter issued by Xinhua News Agency, Russia's supply of crude to China has increased significantly since 2000 compared with Saudi Arabia (see Tables 5.1 and 5.2). In 2018, the volume difference between the two countries was as much as $15 \mathrm{mt}$. Table 5.2 shows that Beijing's initiative to import $20 \mathrm{mt} / \mathrm{y}$ of crude via the trunk pipeline from Kazakhstan failed, as the import figure was a mere $1.3 \mathrm{mt}$ in 2018, and this indirectly explains why Beijing is maximising the ESPO crude supply from Russia to cover the collapsed crude supply from Kazakhstan. ${ }^{5}$

5 Tsvetana Paraskova, 'Kazakhstan Looks to Boost Crude Oil Exports to China', Oil Price, 3 July 2019, oilprice.com/Latest-Energy-News/World-News/Kazakhstan-Looks-To-Boost-Crude-OilExports-To-China.html; 'Kazakhstan to Divert Some Oil Flows from Europe to China', 3 July 2019, Reuters, www.reuters.com/article/us-kazakhstan-china-oil/kazakhstan-to-divert-some-oil-flows-fromeurope-to-china-idUSKCN1TY1W6. 
Table 5.1: China's crude oil imports, 2000-17 (mt/y)

\begin{tabular}{|l|r|r|r|r|r|}
\hline & Middle East & \multicolumn{1}{c|}{ Africa $^{\text {** }}$} & Asia-Pacific & \multicolumn{1}{c|}{ Europe } & \multicolumn{1}{c|}{ Total $^{\star \star *}$} \\
\hline 2000 & 37.65 & 38.47 & 10.61 & 5.05 & 70.27 \\
\hline 2005 & 59.99 & 70.85 & 8.80 & 18.94 & 127.08 \\
\hline 2010 & 112.76 & 70.85 & 8.80 & 25.86 & 239.31 \\
\hline 2015 & 170.16 & 64.46 & 8.31 & 49.85 & 335.49 \\
\hline 2016 & 182.99 & 67.84 & 15.10 & 62.48 & 381.04 \\
\hline 2017 & 182.20 & 82.62 & 14.97 & 73.44 & 419.97 \\
\hline
\end{tabular}

* Saudi Arabia recorded 50.54, 51.00 and 52.18 during 2015-17.

** Angola recorded 38.71, 43.75 and 50.43; ${ }^{* \star \star}$ Latin America/Western hemisphere recorded $42.71,52.63$ and 66.73 .

Source: China OGP, various issues.

Table 5.2: China's crude oil from Russia and Kazakhstan (mt/y)

\begin{tabular}{|l|r|r|}
\hline & \multicolumn{1}{|c|}{ Russia } & Kazakhstan \\
\hline 2000 & 1.77 & 0.65 \\
\hline 2005 & 12.78 & 1.29 \\
\hline 2010 & 15.25 & $10.05^{\star}$ \\
\hline 2015 & 42.43 & 4.99 \\
\hline 2016 & 52.48 & 3.23 \\
\hline 2017 & 59.80 & $2.50^{\star \star}$ \\
\hline
\end{tabular}

Note: In 2018, Russia's crude supply to China reached a record high of $71.5 \mathrm{mt}$.

* The peak volume was $11.3 \mathrm{mt}$ in 2013. ${ }^{6 *}$ Even though not included in this table, the figure of $12.3 \mathrm{mt}$ quoted by Xinhua Net is not accurate. ${ }^{7}$

Source: China OGP, various issues.

6 Paraskova, 'Kazakhstan Looks to Boost Crude Oil Exports to China'.

7 According to PetroChina West Pipeline Co., the China-Kazakhstan pipeline carried a record high $12.3 \mathrm{mt}$ of crude oil into China in 2017. But it is a combination of the total crude from five central Asian republics that passes through the Kazakh-China crude oil pipeline. See, 'Xi Jinping: Persist in Reform and Opening Up, Adhere to High-Quality Development, and Make New and Greater Progress in Accelerating the Construction of a Better Anhui', Xinhua Net, 11 January 2018, www.xinhuanet.com/english/2018-01/11/c_136888551.htm; 'Crude Oil Piped from Kazakhstan to China Reaches Record High', China Daily, 12 January 2018, www.chinadaily.com.cn/a/201801/12/ WS5a584585a3102c394518ed8d.html. As of May 2019, the total crude supply from Kazakhstan to China was $119 \mathrm{mt}$ (CN¥443.8 billion or US\$64.2 billion). The supply volume from January-April 2019 was 3.7 mt. See, 'Nearly 120 Mln Tonnes of Crude Oil Piped from Kazakhstan to China', Global Times, 31 May 2019, www.globaltimes.cn/content/1152532.shtml. From 2006 to July 2014, the accumulated crude supply volume via the pipeline was $70.22 \mathrm{mt}$. See, Zhuwei Wang, 'Securing Energy Flows from Central Asia to China and the Relevance of the Energy Charter Treaty to China', Energy Charter Secretariat, 2015, accessed 22 August 2020, energycharter.org/fileadmin/ DocumentsMedia/Thematic/China_and_the_ECT_2015_en.pdf. 
Russia and Saudi Arabia are engaged in competition to win the biggest market share in China. In late February 2019, during Saudi Crown Prince Mohammed bin Salman's visit to China, Saudi Arabia agreed to form a joint venture with Chinese defence conglomerate Norinco-a refining and petrochemical complex in the north-eastern Chinese city of Panjin worth more than US $\$ 10$ billion. The partners would form a company called Huajin Aramco Petrochemical Co. as part of a project that would include a 300,000 b/d capacity refinery with a $1.5 \mathrm{mt} / \mathrm{y}$ ethylene cracker. Aramco will supply up to 70 per cent of the crude feedstock for the complex, which is expected to start operations in 2024. The investment could help Saudi Arabia regain its place as the top oil exporter to China, a position Russia has held for the last three years. ${ }^{8}$ Saudi's initiative suggests that Rosneft's ill-fated partnership with CEFC China Energy was a major setback, and is a strong signal that competition between Saudi Arabia and Russia will be sustained and possibly intensified in the coming years and decades.

\section{Taas-Yuriakh Saga Exposes the Priority of Rosneft's Asia Strategy}

Rosneft changed its stance towards the Beijing Gas Group (BGG) and entered into a blind partnership with CEFC China without proper due diligence: what drove this move? Until 2015, Rosneft had no difficulty in taking advantage of Chinese national oil companies' (NOCs) very generous loans for oil, but the oil price collapse in 2014-15 forced Rosneft to find new ways to raise money. Rosneft chose to work with a Chinese SOE (state-owned enterprise) and the BGG was the ideal choice. The partial equity disposal of Taas-Yuriakh oil and gas assets to BGG was an easy way to raise money. Rosneft had to make a decision between China's BGG and an Indian consortium. In March 2016, BGG was in the final stage of its due diligence for the Taas-Yuriakh asset, but, on 16 March, Rosneft agreed to sell a large stake to Indian state-run energy companies, including a US $\$ 1.28$ billion share to an Indian consortium.

8 Ben Blanchard, 'Saudi Arabia Strikes \$10 Billion China Deal, Talks De-radicalisation with Xi', Reuters, 22 February 2019, www.reuters.com/article/us-asia-saudi-china/saudi-arabia-strikes-10-billionchina-deal-talks-de-radicalisation-with-xi-idUSKCN1QB15H. 
The group of three Indian companies took a combined 29.9 per cent share in Taas-Yuriakh Neftegazodobycha and a 23.9 per cent stake in Vankorneft. ${ }^{9}$

In March 2014, two months before the POS 1 deal in Shanghai, Reuters reported that Rosneft wanted to break the monopoly of another stateowned energy champion, Gazprom, to export gas via pipelines. It is worth noting that Rosneft and Novatek had already secured rights to export seaborne LNG, reversing a 2006 law that gave Gazprom a monopoly on gas exports. ${ }^{10}$ Two years later, Rosneft's BGG deal revived the pressure towards Gazprom. This touches on the sensitive issue of third-party access to the POS; the assumption is that Rosneft will not give up its attempt to dismantle Gazprom's monopoly of POS 1 . The core of the deal is about providing access to independent gas producers when Gazprom is determined to sustain a single export channel. This purpose was recorded in the protocol of the presidential committee that took place in October 2015. ${ }^{11}$ Third-party access to the pipeline is a political decision and even Igor Sechin cannot give any assurance on this matter, as the final say has to come from Russian President Vladimir Putin.

Separately from this question of third-party access to POS 1, Rosneft was drawing a bigger picture, as it was aiming to enter into India's downstream market. In August 2017, Rosneft and its partners (Trafigura, a global commodity trading and logistics giant, and UCP Investment Group) completed a US\$12.9 billion acquisition of Essar Oil. Reportedly, the new owners, which include Trafigura and UCP Investment Group, will acquire India's largest network of private petrol pumps. ${ }^{12}$

9 'Rosneft Sells 29.9\% of Taas-Yuryakh to Consortium of Indian Cos', Interfax Russia \& CIS Oil and Gas Weekly, 10-16 March 2016, 19-20.

10 'Rosneft Challenges Gazprom Monopoly to Export Russian Pipeline Gas', Reuters, 7 March 2014, www.reuters.com/article/russia-rosneft-gas/update-1-rosneft-challenges-gazprom-monopoly-to-exportrussian-pipeline-gas-idUSL6N0M412120140307.

11 Paik, 'Sino-Russian Oil and Gas Cooperation'.

12 'Essar Oil Completes \$13 Billion Sale to Rosneft-led Consortium in Largest FDI Deal', Economic Times, 22 August 2017, economictimes.indiatimes.com/markets/stocks/news/essar-oil-completes-saleof-india-assets-to-rosneft-for-12-9-bn/articleshow/60154679.cms; Promit Mukherjee, 'Rosneft Seals First Asian Refinery Deal with Essar Oil Purchase', Reuters, 21 August 2017, www.reuters.com/article/ us-india-essar-rosneft/rosneft-seals-first-asian-refinery-deal-with-essar-oil-purchase-idUSKCN1B10PL. 
Ultimately, Rosneft had to allocate the Verkhnechonskoye field (with $\mathrm{C} 1+\mathrm{C} 2$ reserves, $173 \mathrm{mt}$ of oil and condensate, and $115 \mathrm{bcm}$ of gas $)^{13}$ instead of the Taas-Yuriakh field (with $167 \mathrm{mt}$ of oil and condensate, and $181 \mathrm{bcm}$ of gas), which is a part of the Sredne-Botuobinskoye oil, gas and condensate field, to the Indian consortium. ${ }^{14}$ The collapse of the value of the rouble placed Rosneft's top management under extreme pressure. ${ }^{15}$ This may indirectly explain why the hurried deal with the Indian consortium was prioritised. Besides this, Rosneft wanted to show that Russia's flagship oil firm did not bank on one partner only and to build partnerships with several different players.

Another reason for the allocation of the Verkhnechonskoye field asset to BGG lies in the fact that Russia did not want to upset Beijing, which had offered a US\$12 billion loan for gas to Novatek's Yamal LNG project in April 2016. On 29 April 2016, in Beijing, Yamal LNG signed credit agreements with the Export-Import Bank of China (China Exim Bank) and the China Development Bank in the amount of $€ 9.3$ billion and CN¥9. 8 billion for 15 years. The firm said in a statement that the interest rates for the credit lines were EURIBOR $6 \mathrm{M}+3.3$ per cent per annum for the period of construction and 3.55 per cent after the full commissioning of Yamal LNG, and SHIBOR 6M +3.3 per cent and 3.55 per cent per annum, respectively. ${ }^{16}$ However, considering that the gas reserves in the Taas-Yuriakh field are much bigger than that of the Verkhnechonskoye field, Rosneft's decision towards BGG was a face-saving act.

13 'Rosneft and Beijing Enterprises Agreed on Joint Operations on Projects in East Siberia', Rosneft, press release, 25 June 2016, www.rosneft.com/press/releases/item/182759/.

14 'Rosneft Sells 29.9\% of Taas-Yuryakh to Consortium of Indian Cos'.

15 'Rosneft Profits Fall, Customer Pre-Payments Ease Debt Burden', Reuters, 25 November 2015, www.reuters.com/article/russia-rosneft-results-idUSL8N13K1E120151125.

16 'Yamal LNG Signs Credit Agreements with China Exim Bank, China Development Bank', Russia \& CIS Oil and Gas Weekly, 28 April - 4 May 2016, 9; Neil Buckley, 'Sino-Russian Gas Deal: Smoke without Fire', Financial Times, 11 May 2016; James Marson, 'Russian Natural-Gas Project Gets Funding from China: Move Is a Hard-Fought Victory over Western Sanctions', Wall Street Journal, 29 April 2016, www.wsj.com/articles/russian-natural-gas-project-gets-funding-from-china-1461934776. 


\section{Rosneft's III-Fated Partnership with CEFC China Energy}

Rosneft's misfortune continued. It failed to perform proper due diligence on CEFC China Energy's bid to takeover 14.16 per cent equity of Rosneft with the payment of US $\$ 9.1$ billion. ${ }^{17}$ Unfortunately, the ambitious plan collapsed on 1 March 2018 with the arrest of CEFC China Energy Chairman Ye Jianming, who argued that the Rosneft deal was mainly driven by China's Belt and Road Initiative and had strong support from the government. ${ }^{18}$ Rosneft's ill-fated partnership with CEFC China Energy served as indirect confirmation that its honeymoon period with Chinese NOCs for easy financing was over, and there were no private sector alternatives with any real substance. Rosneft had offered an unprecedented discount of ESPO crude supply to Shandong's tea-pot refineries in return for CEFC China Energy's large chunk of equity acquisition. In addition, CEFC China Energy had aimed to penetrate Shandong's gas market by forming an alliance with Qatar and Glencore to take advantage of large-scale LNG supplies at competitive prices. Had this initiative succeeded, Rosneft would have been a major beneficiary of both ESPO crude export and Qatar LNG export to the Shandong province, where no Chinese NOCs had a dominating position. As discussed earlier, Saudi Arabia's low-profile manoeuvring to strike a deal with the Norinco group confirmed Russia’s dominant position as the biggest crude supplier to China; this can be effectively challenged at any time and the intensified competition will serve China well, as China's needs for crude supply will be sustained for a considerable period.

17 Henry Foy, Max Seddon and Lucy Hornby, 'Russia and China Quietly Build Links', Financial Times, 25 September 2017.

18 Andrew Chubb, 'Caixin's Investigation ofCEFC and Chairman Ye Jianming', Southsea Conversations, 29 March 2018, southseaconversations.wordpress.com/2018/03/29/caixins-investigation-of-cefc-andchairman-ye-jianming/; 'CEFC's Rosneft Deal Driven By National Strategy_Chairman', Reuters, 3 October 2017, uk.reuters.com/article/uk-cefc-china-rosneft/cefcs-rosneft-deal-driven-by-nationalstrategy-chairman-idUKKCN1C80ZX; Lucy Hornby and Archie Zhang, 'CEFC Chairman Ye Jianming Said to be Detained', Financial Times, 1 March 2018; 'Russia's Rosneft Says China CEFC Investigation Not Related to it', Reuters, 1 March 2018, www.reuters.com/article/china-cefc-probe-rosneft/russiasrosneft-says-china-cefc-investigation-not-related-to-it-idUSR4N1QG00R; Eric Ng and Xie Yu, 'China Detains CEFC's Founder Ye Jianming, Wiping Out US\$153 Million in Value Off Stocks', South China Morning Post, 1 March 2018, www.scmp.com/business/companies/article/2135238/chinas-presidentorders-arrest-cefcs-founder-ye-jianming-ending. 


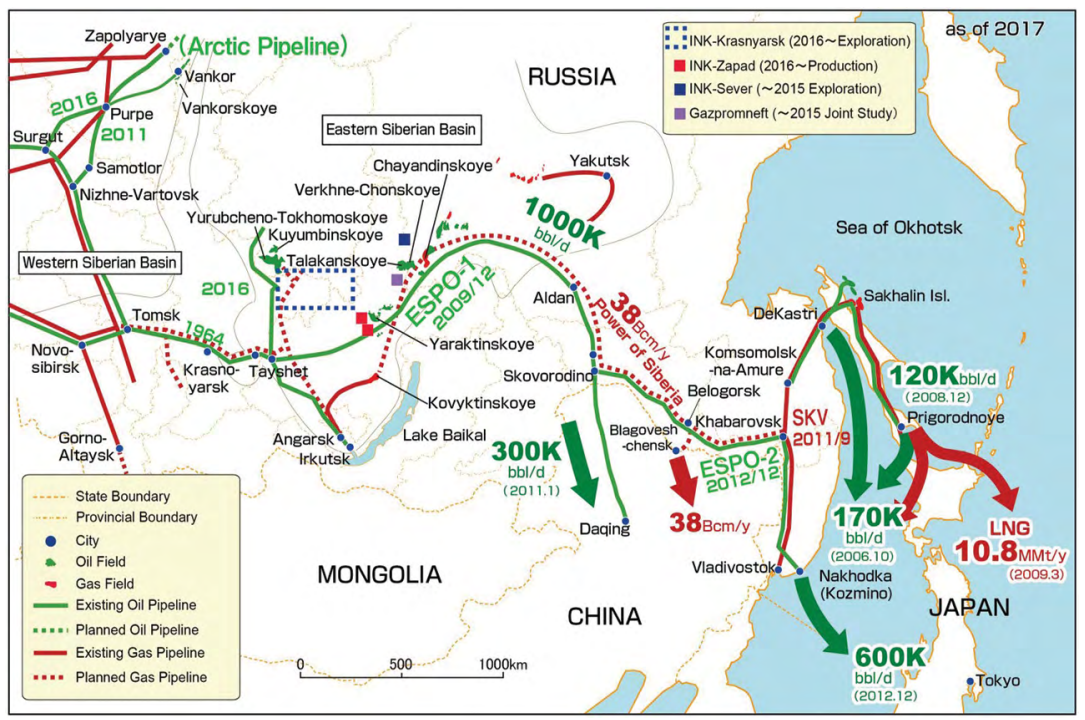

Figure 5.2: Russia's oil and gas export to Asia.

Source: Daiske Harada, 'Rising Gas Flow from Russia to East: Current Status, Role of the Arctic Challenges in the future', paper presented at 2018 LNG Congress, Russia. Harada is an officer of the Japan Oil, Gas and Metals National Corporation.

In this context, it is not surprising that Rosneft wanted to switch its obligations to CEFC China Energy from the arm based in China to that based in Singapore, thereby demonstrating its continued commitment to the Chinese firm, despite the failed privatisation deal. Rosneft stated that its board would consider a deal transferring obligations from CEFC China Energy Co. Ltd to CEFC Shanghai International Group (Singapore) Pte Ltd on 25 January 2019. CEFC Shanghai is a CEFC trading arm that receives crude oil supplies from Rosneft and trades them further. ${ }^{19}$ The improvised damage control initiative was a minimum requirement to protect Russia's share in China's big oil market.

19 Sources familiar with the matter said CEFC would take eight cargoes of ESPO blend crude oil and two cargoes of Urals crude in March from Rosneft, indicating no change in volume for 2019. See, Vladimir Soldatkin and Florence Tan, 'Rosneft Switches Dealing to Singapore Arm of China's CEFC, No Change in Oil Volumes', Reuters, 22 January 2019, uk.reuters.com/article/rosneftchina-oil/rosneft-switches-dealing-to-singapore-arm-of-chinas-cefc-no-change-in-oil-volumesidUKL8N1ZM27I; 'China's CEFC Paid Out Compensation after Rosneft Stake Deal Fell through', Reuters, 30 November 2018, uk.reuters.com/article/uk-rosneft-privatisation-cefc/chinas-cefc-paidout-compensation-after-rosneft-stake-deal-fell-through-idUKKCN1NO1RW; 'Qatar to Take Stake in Russia’s Rosneft after Deal with China Falls through', RadioFreeEurope RadioLiberty, 5 May 2018, www.rferl.org/a/qatar-takes-20-percent-stake-russia-rosneft-oil-giant-after-deal-with-china-cefc-fallsthrough/29209725.html. 
The most important and urgent task for Rosneft is to identify recoverable oil reserves in its frontier areas to sustain its crude supply capacity to the Asian market. Transneft launched two new pipelines to link green fields in northern and Eastern Siberia to its pipeline network in 2017. The Zapolyarye-Purpe line, with an initial capacity of $25 \mathrm{mt} / \mathrm{y}(0.5 \mathrm{mb} / \mathrm{d})$ and expansion potential of up to $45 \mathrm{mt} / \mathrm{y}$, runs $488 \mathrm{~km}$ across West Siberia, and can deliver crude both westward and eastward. The $700 \mathrm{~km}$ KuyumbaTaishet, with an initial capacity of $8.6 \mathrm{mt} / \mathrm{y}$, runs across East Siberia's Krasnoyarsk and Irkutsk regions to the ESPO pipeline for deliveries to Asian markets and domestic refineries. ${ }^{20}$

Northern Siberia is among Russia's most promising new oil provinces. Lukoil's Pyakyakhinskoye field became the first source of crude for the Zapolyarye-Purpe pipeline, followed by the East Messoyakha field, being developed jointly by Gazprom Neft and Rosneft. Regarding the second pipeline, it is scheduled for expansion to $15 \mathrm{mt} / \mathrm{y}$ by 2023, but the actual pace of the work will be dependent on the progress of the Kuyumba field, being developed jointly by Gazprom Neft and Rosneft, and the Yurubcheno-Tokhomskoye field, being developed by Rosneft and the China National Petroleum Corporation (CNPC). ${ }^{21}$ It remains to be seen whether new reserves in Russia's Arctic circle will be large enough to sustain the export volume needed for Asia's markets.

In short, Rosneft's export policy towards Asia boils down to the fact that, while China is a very important market for Russia, it is not the only market. That is why Rosneft played the China card and the India card simultaneously. However, the price Rosneft had to pay for its failure to take advantage of the BGG deal in terms of penetrating China's gas market was very high. Without third-party access to the POS 1 gas pipeline, Rosneft's attempt to penetrate China's gas market in the coming decades will be a very tough struggle.

20 Rodova, 'Transneft Sees Fast Growth in Arctic'.

21 Rodova, 'Transneft Sees Fast Growth in Arctic'. 


\section{Gazprom: Starting the POS 1 Gas Supply- No Sign of Altai Gas}

Sino-Russian gas cooperation has been a long march with many ups and downs. Gazprom's former CEO Rem Vyakhirev began the process in 1997, but the company delivered no tangible results until May 2014, when the POS 1 gas deal was finally signed. ${ }^{22}$ According to the Financial Times, Russia's first eastern pipeline is the most striking physical manifestation of Putin's diplomatic pivot towards China in response to deteriorating relations with the West. ${ }^{23}$ From December 2019, the pipeline delivered gas at a pilot volume of $5 \mathrm{bcm} / \mathrm{y}$, and is expected to increase to its full capacity of $38 \mathrm{bcm} / \mathrm{y}$ by $2024 .{ }^{24}$ In the short term, the pipeline's impact on China's LNG imports will not be that significant. It is worth noting that the gas demand from Heilongjiang, Jilin, Liaoning and Hebei (where Beijing and Tianjin are located) provinces will not be large enough to absorb the whole $38 \mathrm{bcm} / \mathrm{y}$. It is fair to say that the $25 \mathrm{bcm} / \mathrm{y}$ that comes from the Chayandinskoye field will not face any challenge from the LNG supply to the Bohai gas market, but the remaining $13 \mathrm{bcm}$ of Kovykta gas will be vulnerable when it is extended from Shandong and Jiangsu provinces and Shanghai, as the price will not be that competitive.

From Gazprom's viewpoint, the domestic supplier's challenge to break-up Gazprom's monopoly and open the door for third-party access to POS 1 is the more important issue. To block third-party access for independent gas producers in East Siberia's stranded gas reserves, Gazprom has mapped out its grand supply plan by accelerating the connection of Chayandinskoye gas with Kovykta gas with the $800 \mathrm{~km}$ pipeline.

By 2020, Chayandinskoye had some 59 new production wells in addition to the 149 existing wells. Plans had advanced slowly to sell gas containing ethane-propane-butane fractions to China through POS 1. Gazprom will separate ethane-propane-butane and helium from methane at the planned $42 \mathrm{bcm} / \mathrm{y}$ Amur Gas Processing Plant from 2021, by which time three

22 For the background of Gazprom's export strategy towards China, see Keun-Wook Paik, SinoRussian Oil and Gas Cooperation: The Reality and Implications (Oxford: Oxford University Press, 2012). 23 Henry Foy, 'Russia Takes \$55 Bn Punt on Pipeline to Satisfy Chinese Demand for Gas', Financial Times, 4 April 2018.

24 'Power of Siberia', Gazprom, accessed 22 August 2020, www.gazprom.com/projects/power-ofsiberia/; 'Power of Siberia', Gazprom Export, accessed 4 September 2020, www.gazpromexport.ru/en/ projects/transportation/3/. 
trains with a combined capacity of $21 \mathrm{bcm} / \mathrm{y}$ are due on line, and gas output from Chayandinskoye will have risen to $13.8 \mathrm{bcm} / \mathrm{y}$, as shown in Table 5.3. The firm aims to commission a further three trains in 2022-24.

Table 5.3: Chayandinskoye and Kovyktinskoye output (bcm/y)

\begin{tabular}{|l|r|r|}
\hline & Chayandinskoye & Kovyktinskoye \\
\hline 2019 & 1.5 & - \\
\hline 2020 & 6.9 & - \\
\hline 2021 & 13.8 & - \\
\hline 2022 & 19.2 & - \\
\hline 2023 & 23.6 & 4.9 \\
\hline 2024 & 25.0 & 15.0 \\
\hline 2025 & 25.0 & 25.0 \\
\hline 2045 & 25.0 & 25.0 \\
\hline 2050 & - & 25.0 \\
\hline
\end{tabular}

Source: 'Gazprom Prepares for China Exports', Argus FSU Energy, 30 May 2019, 1.
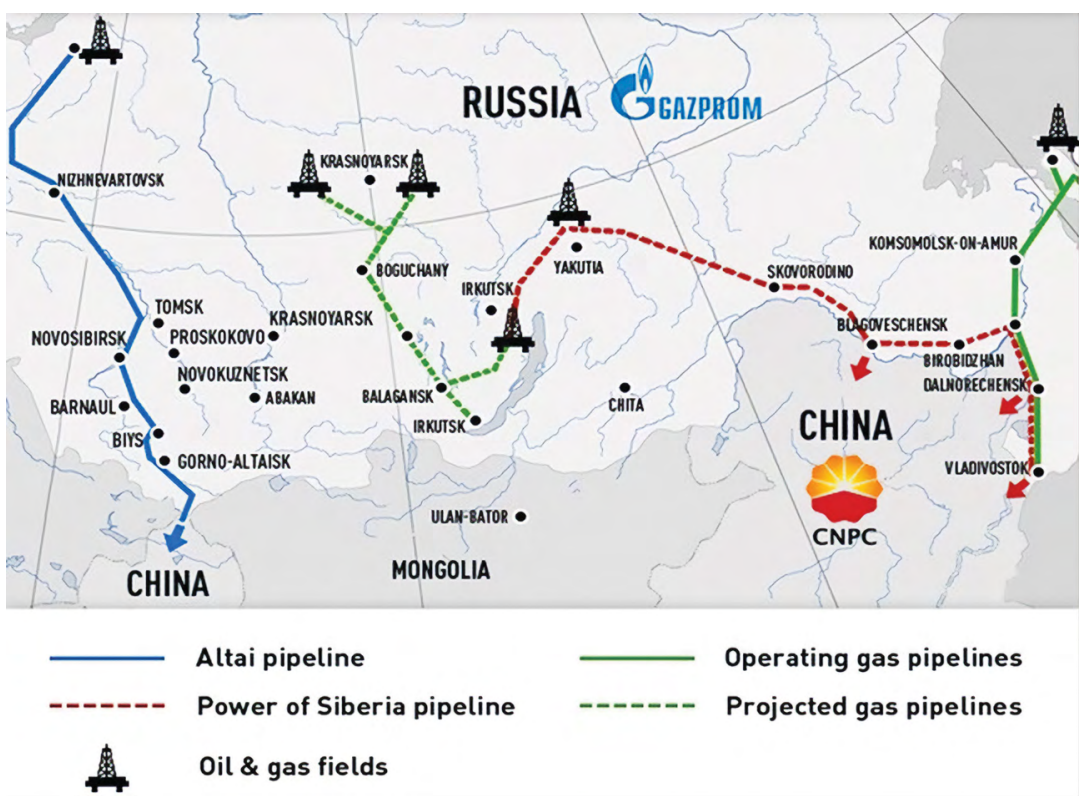

Operating gas pipelines

Projected gas pipelines

\section{Figure 5.3: Gazprom's POS 1 and Altai gas to China.}

Source: This map was frequently used by Gazprom to advertise the 2014 POS 1 deal, but it is rarely used now. 
Gazprom intended to begin the first seven production wells at Dobycha Irkutsk's Kovykta in 2019, and the firm envisages drilling a further 289 production wells by 2047 , eventually rising to a total 514 . It will also construct five gas and condensate treatment facilities. Construction of the first three treatment plants began in 2020 and they should be commissioned in 2023-25. Gazprom plans to bring Kovykta on line in late 2022, targeting production at $5 \mathrm{bcm} / \mathrm{y}$ in 2023 and reaching a plateau of $25 \mathrm{bcm} / \mathrm{y}$ in 2025 that will be maintained until 2045. Almost all of the Kovykta gas will go through the Kovykta-Chayandinskoye $800 \mathrm{~km}$ pipeline that should be commissioned in late 2022, with a $48 \mathrm{MW}$ head compressor station at Kovykta. ${ }^{25}$ Gazprom will use $1.4 \mathrm{bcm}$ for its own needs over the next 2,000 km through the Yakutia and Amur regions, and another $2.6 \mathrm{bcm}$ will be used for gasification. A total of $44 \mathrm{bcm}$ will be delivered to the Amur Gas Processing Plant with $41 \mathrm{bcm}$ leaving once valuable natural gas components have been taken out. Of this, $1 \mathrm{bcm}$ will be sent to the Amur Gas Chemicals Complex, $1 \mathrm{bcm}$ will be sidelined for gasification in Amur and another $1 \mathrm{bcm}$ for the needs of the Zeyskaya compressor station. ${ }^{26}$

Gazprom's other main task is the long-delayed POS 2 or Altai gas pipeline development. Since the May 2014 POS 1 breakthrough, Gazprom has paid little more than lip-service to the Altai gas pipeline development. Had Turkmenistan proceeded with the D Line construction, it would have been impossible for Gazprom to strike the Altai gas deal with CNPC. The delayed construction of the D Line enabled Gazprom to explore a fast tracked Altai gas line.

In May 2018, according to figures from pipeline officials in Kazakhstan, deliveries through the three existing strands of the 2,000 km (1,242 mile) cross-border network will rise by nearly a third from the $38.7 \mathrm{bcm}$ supplied to China in 2017. The planned volumes of $51.37 \mathrm{bcm}$ would be

25 'Gazprom Outlines Kovykta Plans', Argus FSU Energy, 18 October 2019, 1.

26 'Gazprom Considering Possibility of Increasing Gas Exports to China Via Power of Siberia up to $48 \mathrm{bcm}$ per Year', Interfax Russia \& CIS Oil and Gas Weekly, 29 November - 5 December 2018, 30. See, 'Amur Gas Processing Plant', Gazprom, accessed 22 August 2020, www.gazprom. com/projects/amur-gpp/. For Sibur Amur GCC (Gas Chemicals Complex), see 'Growth Projects', Sibur25, accessed 22 August 2020, www.sibur.ru/en/about/investments/16906/. See also 'Sinopec Signs Agreement to Take Stake in Amur Petchems Project in Russia', HIS Markit, accessed 22 August 2020, ihsmarkit.com/research-analysis/sinopec-signs-agreement-to-take-stake-in-amur-petchemsproject.html; Dina Khrennikova, 'Russia's Largest Chemicals Company Is Plowing Ahead with Saudi, China Deals', Bloomberg, 21 February 2019, www.bloomberg.com/news/articles/2019-02-21/russias-sibur-revives-project-plans-in-china-saudi-arabia. 
perilously close to the Central Asian Gas Pipeline's (CAGP) rated capacity of $55 \mathrm{bcm}$ per year. The constraint could have serious consequences for China's huge investments over the past decade in Turkmenistan. ${ }^{27}$ The Central Asian capacity problem would force China to deepen its growing reliance on LNG imports as the country is seeking to reduce pollution from coal. From the start of imports in 2010 until 2019, the CAGP's A, $\mathrm{B}$ and $\mathrm{C}$ lines carried $203.2 \mathrm{bcm}$ to China, nearly equal to the country's total consumption in 2016. The scheduled imports from Central Asia in 2018 included $38.7 \mathrm{bcm}$ from Turkmenistan, $7.6 \mathrm{bcm}$ from Uzbekistan and more than $5 \mathrm{bcm}$ from Kazakhstan. ${ }^{28}$

Beijing has wanted to introduce a new $1,000 \mathrm{~km}$ (621 mile) D Line to China since 2013, but the plan has been subject to repeated delays. The new D Line from Turkmenistan through Uzbekistan, Tajikistan and Kyrgyzstan would carry $25-30 \mathrm{bcm} / \mathrm{y}$ to China's western border. But, despite official target dates for completion-initially in 2016 and then in 2020-the most recent reports suggest that it will be commissioned no sooner than the end of 2022. Although the new line would diversify China's routes and avoid excessive reliance on transit through Kazakhstan, it would not diversify supplies. Equally important is the apparent failure to coordinate the expansion of the CAGP with the explosion in China's gas demand during the winter of 2017, when the National Development and Reform Commission (NDRC) ordered a ban on coal-fired heating in 28 northern cities. To make matters worse, CAGP volumes dropped by half at the end of January 2018 due to 'frequent equipment failures' in Turkmenistan, according to a CNPC statement at the time. The outages highlighted China's dependence on Central Asian gas. In 2017, Turkmenistan's gas production fell 7.1 per cent to $62 \mathrm{bcm}$, marking the first annual decline since 2009. ${ }^{29}$

27 Michael Lelyveld, 'China Nears Limit on Central Asian Gas', Radio Free Asia (RFA), 25 June 2018, www.rfa.org/english/commentaries/energy_watch/china-nears-limit-on-central-asian-gas-062 52018100827.html; Dominique Patton, 'Central Asia—China Gas Pipeline to Hit Maximum Capacity_PetroChina', Reuters, 12 November 2018, www.reuters.com/article/china-gas-petrochinaidAFL4N1XN3DF.

28 Lelyveld, 'China Nears Limit on Central Asian Gas'; Patton, 'Central Asia-China Gas Pipeline'.

29 Lelyveld, 'China Nears Limit on Central Asian Gas'. 


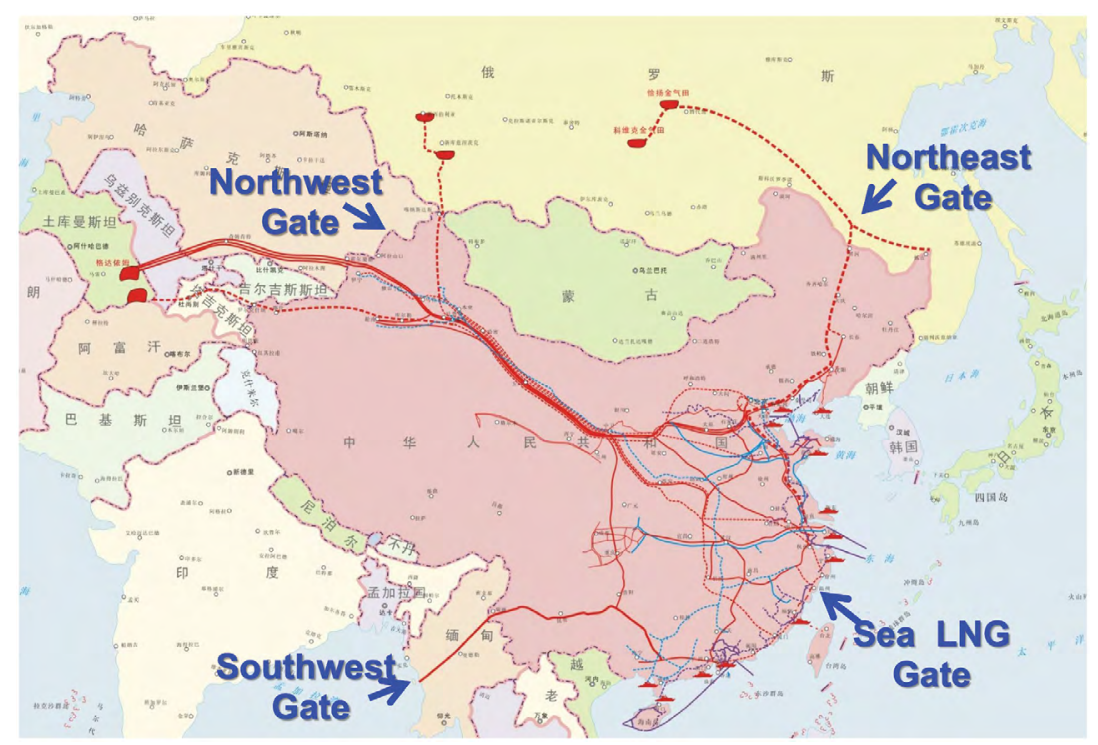

Figure 5.4: China's gas imports by pipeline and LNG.

Source: China National Petroleum Corporation.

Turkmenistan's failure to supply sufficient gas to China revived the chances for West Siberian gas. However, CNPC and Gazprom have made no announcements about Altai gas, despite Chinese President Xi Jinping commenting on Altai gas at the Vladivostok Economic Forum in September 2018. ${ }^{30}$ Interfax reported Nur Bekri, Director of China's NDRC NEA (National Energy Administration), as stating that:

We expect in the end, China will receive $30 \mathrm{bcm}$ of gas from the western route $\ldots$ in time, and given supplies from the eastern route $(38 \mathrm{bcm})$ as well as LNG, overall Russian gas supplies might rise to $80 \mathrm{bcm} .^{31}$

30 Witold Rodkiewicz and Michal Bogusz, 'The Eastern Economic Forum in Vladivostok. In the Shadow of Russian-Chinese Cooperation', OSW, 14 September 2018, www.osw.waw.pl/en/publikacje/ analyses/2018-09-14/eastern-economic-forum-vladivostok-shadow-russian-chinese-cooperation; Michael Lelyveld, 'China, Russia May Vie for Turkmenistan's Gas', RFA, 6 May 2019, www.rfa. $\mathrm{org} /$ english/commentaries/energy_watch/china-russia-may-view-for-turkmenistans-gas-050620 19104507.html.

31 'Task Set to Sign Contract on Gas Supply to China Via Western Route before End of YearKozak', Interfax Russia \& CIS Oil and Gas Weekly, 13-19 September 2018, 9-13. 
Ultimately, the market provider will dictate the terms and conditions of pipeline gas supply. If no breakthrough on the Altai line is made, Beijing will have no choice but to maximise the supply of LNG, including Russia's Arctic LNGs.

The target supply time and competitive pricing of Novatek's Arctic LNG 2 to markets like Shandong, Jiangsu and Shanghai, with prices that could be substantially lower than LNG supplied from Qatar, Australia and the US, makes it Gazprom's main competition for its Altai line; in the end, price will be the biggest issue. If Novatek finds a way to duplicate the scale of its Arctic LNG 2 (19.8 mt/y) by 2025-26, it will deliver a massive challenge to Gazprom's POS 2 or Altai gas supply to China. Despite considerable talk and deal making, it is not clear whether or when the POS 2 will be built.

There is another difficult task facing Gazprom in the Baltic area. Gazprom and Shell's flagship LNG project was derailed in April 2019, forcing Gazprom to prove its capacity to perform with a Russian partner. Gazprom agreed to work with RusGazDobycha to build an LNG plant at the Russian Baltic port of Ust-Luga, a decision that forced Shell to stop the project with Gazprom. ${ }^{32}$ This is because RusGazDobycha's unheralded arrival was accompanied by changes to the configuration of the project, which Shell did not feel comfortable with. ${ }^{33}$ No explanation has been provided for why Gazprom brought RusGazDobycha into the Baltic LNG project, and questions remain about how seriously Shell's departure will affect the project's price competitiveness. The outcome should be known during the first half of 2020s.

32 The plant will process $45 \mathrm{bcm} / \mathrm{y}$ of gas with a high ethane content from the deeper Achim and Valazhin formations in West Siberia's Nadym-Pur-Taz area. The plant foresees $25 \mathrm{bcm}$ of the processed gas being used to produce $13 \mathrm{mt} / \mathrm{y}$ of LNG, $4 \mathrm{mt} / \mathrm{y}$ of ethane and $2.2 \mathrm{mt} / \mathrm{y}$ of LPG, with the remaining $20 \mathrm{bcm} / \mathrm{y}$ going into Gazprom's network. The Ust-Luga plant will have two $6.5 \mathrm{mt} / \mathrm{y}$ LNG trains, commissioned in 2023 and 2024, with the same deadlines for ethane and LPG production startup, respectively. Gazprom estimates the facilities will cost over $\mathrm{P700}$ billion (US $\$ 10.7$ billion). See, 'Gazprom Agrees New Baltic LNG project', Argus FSU Energy, 4 April 2019, 4.

33 Dmitry Zhannikov and Olesya Astakhova, 'Arrival of Putin's Judo Partner Squeezed Shell Out of LNG Project-sources', Reuters, 11 April 2019, uk.reuters.com/article/us-gazprom-shellexit-exclusive/exclusive-arrival-of-putins-judo-partner-squeezed-shell-out-of-lng-project-sourcesidUKKCN1RN2K5; 'Gazprom Drilling Company Named its Owners', Rus Letter, 13 January 2018, rusletter.com/articles/gazprom_drilling_company_named_its_owners; 'Arkady Rotenberg and Gennady Timchenko Will Share with Gazprom the Most Expensive', Rus Letter, 29 March 2019, rusletter.com/articles/arkady_rotenberg_and_gennady_timchenko_will_share_with_gazprom_the_ most_expensive; 'Russia’s Baltic LNG: Gazprom Stays, Shell Quits, Rotenberg Brothers Enter the Game', Warsaw Institute, 25 April 2019, warsawinstitute.org/russias-baltic-lng-gazprom-stays-shellquits-rotenberg-brothers-enter/. 


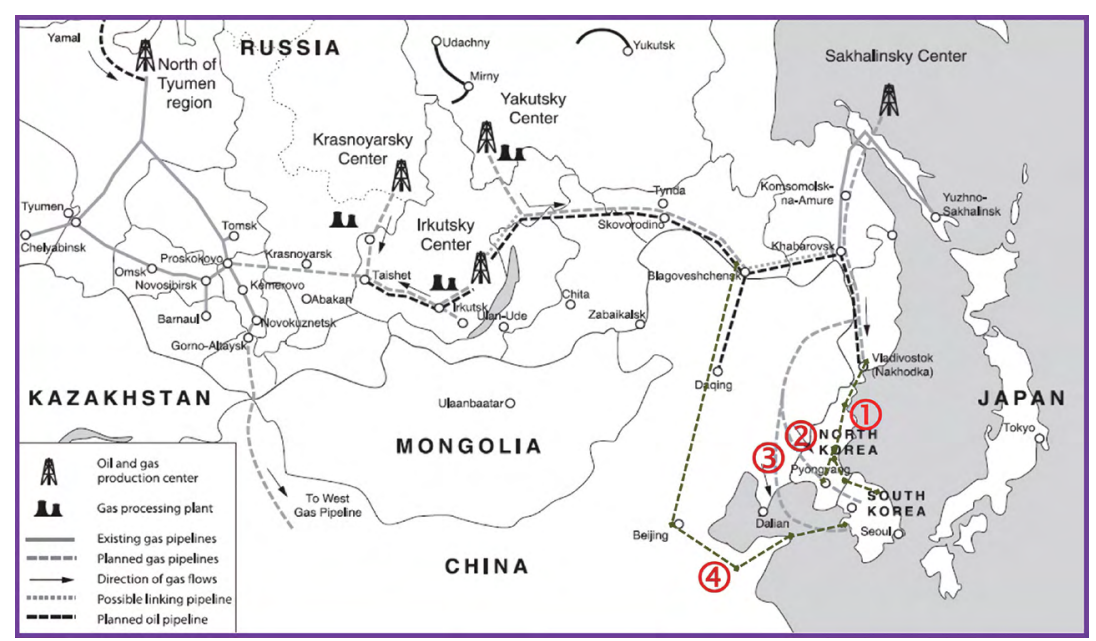

Figure 5.5: Pipeline gas supply options to the Korean Peninsula.

Source: Gazprom and Russian Petroleum Investor, 2018.

The export of Sakhalin offshore gas via the Sakhalin-KhabarovskVladivostok gas pipeline is another area of difficulty for Gazprom. If timely development can be guaranteed, Sakhalin offshore gas can be allocated either to China's Jilin province or the Korean Peninsula during the second half of the 2020s. However, if the first Sakhalin line's $8 \mathrm{bcm} / \mathrm{y}$ gas is not available for the second Sakhalin line's third train expansion $(5.4 \mathrm{mt} / \mathrm{y})$, there will be only $5.5 \mathrm{bcm} / \mathrm{y}$ from Kirinsky in 2021, and then $8 \mathrm{bcm} / \mathrm{y}$ from South Kirinksy by 2023. (The plateau of $21 \mathrm{bcm} / \mathrm{y}$ will be reached by 2033-34). ${ }^{34}$ If Gazprom aims to supply $10 \mathrm{bcm} / \mathrm{y}$ or $7 \mathrm{mt} / \mathrm{y}$ of Sakhalin offshore gas to the Korean Peninsula, the earliest this could occur would be in second half of the 2020s. Separate from the volume supply issue is price. Authorities in Seoul have repeatedly advertised that imported gas from the pipeline gas will be 30 per cent cheaper than LNG, but this is somewhat misleading. ${ }^{35}$ The cost of producing the offshore gas will be high. Unless Putin decides to make a political gesture, the price of this gas will not be 30 per cent cheaper than LNG.

34 'Gazprom Prioritises China-focused Projects', Argus FSU Energy, 21 March 2019, 3; 'Crunch Time for Sakhalin 2 Third Train', Argus FSU Energy, 13 December 2018, 6; 'China Gas Talks Move up a Gear', Argus FSU Energy, 20 September 2018, 1.

35 Jeanne Choi, 'Development in Russian-Asian Energy Cooperation. Interview with Keun-Wook Paik', National Bureau of Asian Research (NBR), 26 July 2018, www.nbr.org/research/activity.aspx? id $=884$. 
In short, the start of POS 1's gas supply at the end of 2019 to northern China's gas market will not affect LNG supply that significantly. The greater impact will come from Novatek's Arctic LNG 2-but only if the price is competitive. The introduction of POS 2 is another factor that will affect China's LNG imports in the coming decades.

Before discussing the impressive performance of Novatek's Arctic onshore gas-based LNG exports, it is worth noting where China's gas expansion stands at present. In 2018, China's gas demand reached $280.4 \mathrm{bcm}$ (or $196.3 \mathrm{mt}$ ) and the country imported $90.1 \mathrm{mt}$ of gas, of which $53.9 \mathrm{mt}$ was LNG and $36.2 \mathrm{mt}$ came by pipeline, according to data by the General Administration of Customs. This solidified China's position as the world's biggest importer of natural gas. In 2017, the figure was $38.3 \mathrm{mt}$ of LNG and $30.4 \mathrm{mt}$ of piped gas. LNG demand growth slowed to 40.8 per cent year on year in 2018 compared with 46.4 per cent in 2017. In contrast, Chinese pipeline imports increased by 20.3 per cent year on year in 2018 compared with 8.8 per cent in 2017. China's gas demand in 2019 was projected to be $308 \mathrm{bcm} .{ }^{36}$ In 2019 , China's total gas imports were projected to be $143 \mathrm{bcm}$, a 14 per cent increase from 2018, which is equivalent to $124 \mathrm{bcm}$ or $90.39 \mathrm{mt}$ (a 32 per cent increase from 2017). ${ }^{37}$

During the LNG2019 conference in Shanghai, CNOOC Vice President $\mathrm{Li}$ Hui said that China was expected to import $57 \mathrm{bcm}$ of pipeline gas in 2019 and $63 \mathrm{bcm}$ in 2020. He added that China's piped offtake would surge in the early 2020s, reaching $121.8 \mathrm{bcm}$ by 2025 and $126 \mathrm{bcm}$ in 2030, representing a 121 per cent increase from the 2019 figure.

36 Chen Aizhu and Henning Gloystein, 'China Gas Demand to Surge in 2019, but Maybe Not Enough to Sop Up LNG Glut', Reuters, 8 April 2019, www.reuters.com/article/us-chinagas-beijinggas/china-gas-demand-to-surge-in-2019-but-maybe-not-enough-to-sop-up-lng-glutidUSKCN1RK0BW; 'Cold Snap Boosts Gas Demand but Slowdown Beckon', Argus China Petroleum, January 2019, 13; 'China's Imports of Crude Oil, Natural Gas Surge in 2018', China Daily, 21 January 2019, www.chinadaily.com.cn/a/201901/21/WS5c458568a3106c65c34e5a7c. html; Tsvetana Paraskova, 'Breakneck LNG Demand Surge in China Is History', Oil Price.Com, 2 February 2019, oilprice.com/Energy/Gas-Prices/Breakneck-LNG-Demand-Surge-In-China-IsHistory.html\#.

37 In 2018, China paid an average price of US $\$ 6.14 \mathrm{mmbtu}$ for its pipeline purchases, which was considerably cheaper than the US $\$ 9.58$ mmbtu average it paid for LNG. See, Colin Shek, 'China's Slowing Economy to Drag on Gas Demand Growth', Interfax Energy, 17 January 2019, interfaxenergy.com/gasdaily/article/33847/chinas-slowing-economy-to-drag-on-gas-demand-growth (site discontinued). 


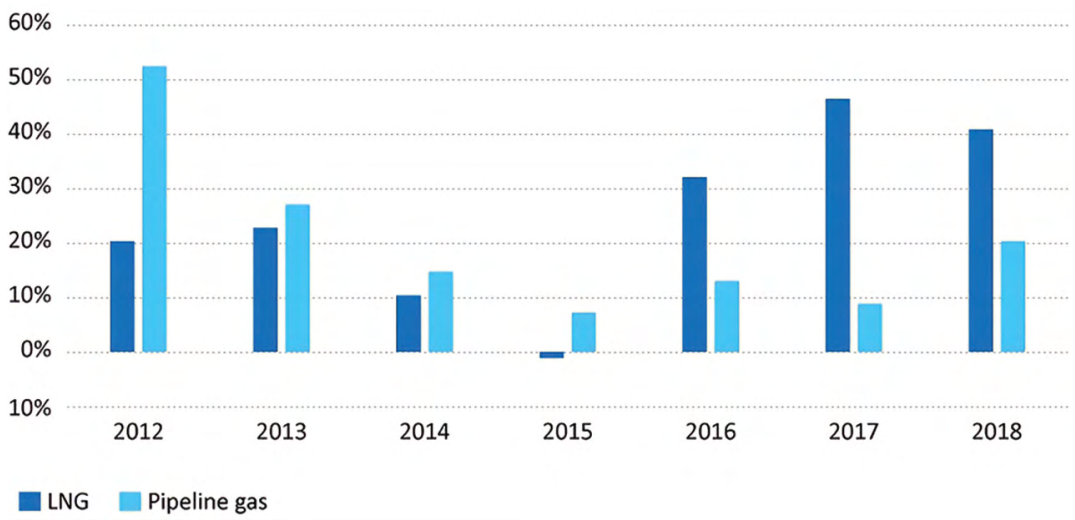

\section{Figure 5.6: Chinese LNG and pipeline gas import growth.}

Source: Colin Shek, 'LNG Expands Dominance of China's Gas Import Mix', Interfax Gas Daily, 28 January 2019.

China's LNG imports reached $50 \mathrm{bcm}$ in 2019 , rising only slightly to $50.8 \mathrm{bcm}$ in 2020. CNOOC expects imports to rise slowly in the second half of the 2020s, reaching $83 \mathrm{mt}(116.2 \mathrm{bcm})$ in 2025 and $88.6 \mathrm{mt}(124$ $\mathrm{bcm}$ ) in 2030. This would equate to growth of 48 per cent between 2019 and $2030 .^{38}$

In 2018, China's pipeline gas imports recorded $52 \mathrm{bcm} .{ }^{39}$ Pipeline gas growth was even stronger in 2019, as Kazakhstan agreed in October 2018 to double exports to China to $10 \mathrm{bcm}$ in 2019. CNPC's research arm ETRI (Economic and Technology Research Institute) has predicted that pipeline imports will hit $65 \mathrm{bcm}$ in 2020 and will double to $130 \mathrm{bcm}$ by 2030. An executive from PetroChina stated at LNG 2019 that China's LNG imports could hit $110 \mathrm{bcm}$, equivalent to $80 \mathrm{mt} / \mathrm{y}$, by $2025 .{ }^{40}$ According to executives at CNOOC and CNPC, the volume of pipeline gas projected to be imported by 2030 is between 126 and $130 \mathrm{bcm} / \mathrm{y}$; this is in line with the volume Bernstein projected with only one pipelineAltai gas or $\mathrm{D}$ line—as shown in the Table 5.4. If both pipelines are introduced, it will scale down China's LNG import volume in 2030.

38 Colin Shek and Tang Tian, 'China's Piped Imports to Surpass LNG Shipments in Long Run', Interfax Energy, 5 April 2019, interfaxenergy.com/article/34099/chinas-piped-imports-to-surpasslng-shipments-in-long-run (site discontinued).

39 'China’s LNG Imports Could Reach 110 Bln Cubic Meters by 2025: CNPC', Reuters, 3 April 2019, www.reuters.com/article/us-shanghai-lng-conference-cnpc/chinas-lng-imports-could-reach-110bln-cubic-meters-by-2025-cnpc-idUSKCN1RF0UG.

40 Shek and Tian, 'China's Piped Imports'. 


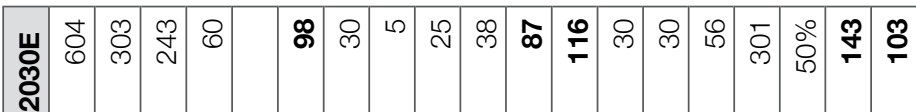

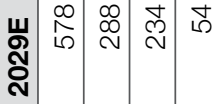

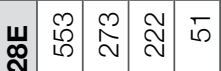
ลิ

岕

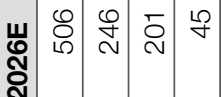

岕 ลิ่

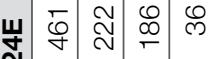

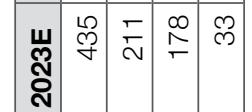
$\stackrel{7}{\circ}$

: ํํำ

ह

के

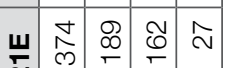
ลิ่

क윽

$\stackrel{8}{\mathscr{8}}$

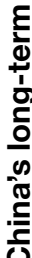

-

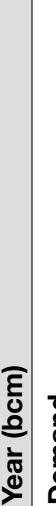

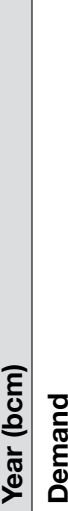

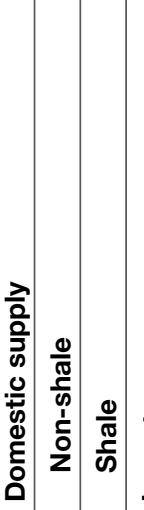

:

ஜ

ஜ

\&

\&

๑

๑

일

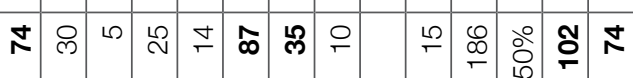

$\infty$

\begin{tabular}{lll|ll}
$\varangle$ & 0 & 0 & 0 \\
1 & 1 & 0
\end{tabular}

$\frac{\pi}{2}$

童

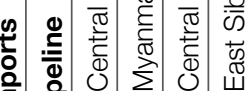

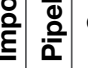


Nonetheless, China's LNG expansion will continue, as CNOOC will still go ahead with a major expansion of its regasification capacity in the next decade. CNOOC will have $80 \mathrm{mt} / \mathrm{y}$ of regasification capacity by 2030 , according to CNOOC Chairman Yang Hua. The company currently operates $45.2 \mathrm{mt} / \mathrm{y}$ of regasification capacity across 10 terminals and has long-term supply contracts for $24.8 \mathrm{mt} / \mathrm{y}$ of LNG. It imported $26.4 \mathrm{mt}$ of LNG and supplied $51.1 \mathrm{bcm}$ of gas in 2018, accounting for 18 per cent of China's gas supply. CNOOC will expand the capacity of its existing LNG terminals in Tianjin, Shanghai and Fujian provinces between 2019 and 2030 while building two new terminals at the provinces of Jiangsu and Fujian. ${ }^{41}$ CNOOC's role in China's LNG expansion is pivotal; that it bought 10 per cent equity in Novatek's Arctic LNG 2 project was a bold but unsurprising move.

\section{Novatek: Arctic Onshore LNG Becomes a Real Game Changer}

With most of the Western media's attention focused on the US shale revolution and the US's related LNG export capacity expansion during the 2010s, little attention was paid to Novatek's Yamal LNG development. In December 2017, with the official opening of Yamal LNG's operation at Sabetta, the Western world saw that Novatek had managed to deliver the project on time and on budget. ${ }^{42}$ The same month, Novatek CFO Mark Gyetvay confirmed the firm's plan to create a major LNG production centre in the Russian Arctic Zone to rival Qatar, Australia and the US. ${ }^{43}$ This Arctic onshore gas-based LNG export initiative signalled Russia's

\footnotetext{
41 Shek and Tian, 'China's Piped Imports'.

42 'Ceremony of First Tanker Loading Under the Yamal LNG Project', President of Russia, 8 December 2017, en.kremlin.ru/events/president/news/56338; 'Yamal LNG Project Reaches Full Production Capacity', Xinhaua News, 12 December 2018, www.xinhuanet.com/english/2018-12/12/ c_137666821.htm; Vladimir Soldatkin and Oksana Kobzeva, 'Russia Offers to Sell Gas to Saudi Arabia from Yamal LNG', Reuters, 8 December 2017, www.reuters.com/article/us-russia-lng-novatek/russiaoffers-to-sell-gas-to-saudi-arabia-from-yamal-lng-idUSKBN1E22HR; Keun-Wook Paik, 'The Arctic as a Future Global Natural Gas Supply Hub', in A North Pacific Dialogue on Arctic Futures: Emerging Issues and Policy Responses, ed. Robert W. Corell, Jong Deog Kim, Yoon Hyung Kim and Oran R. Young (KMI and East-West Centre, December 2016), 239-51, www.eastwestcenter.org/sites/default/files/file manager/pubs/pdfs/Arctic2016/2016arctic-01frontmatter.pdf.

43 Henry Foy, 'Novatek Widens Arctic LNG Ambitions', Financial Times, 13 December 2017; 'Exclusive Interview: Novatek CFO Mark Gyetvay', Riveria, accessed 22 August 2020, www.rivier amm.com/opinion/exclusive-interview-novatek-cfo-mark-gyetvay-54658.
} 
strong desire to become a major player-perhaps even a game changerin the coming years. The role of Novatek will be decisive in transforming Russia into a competitively priced global supplier of LNG.

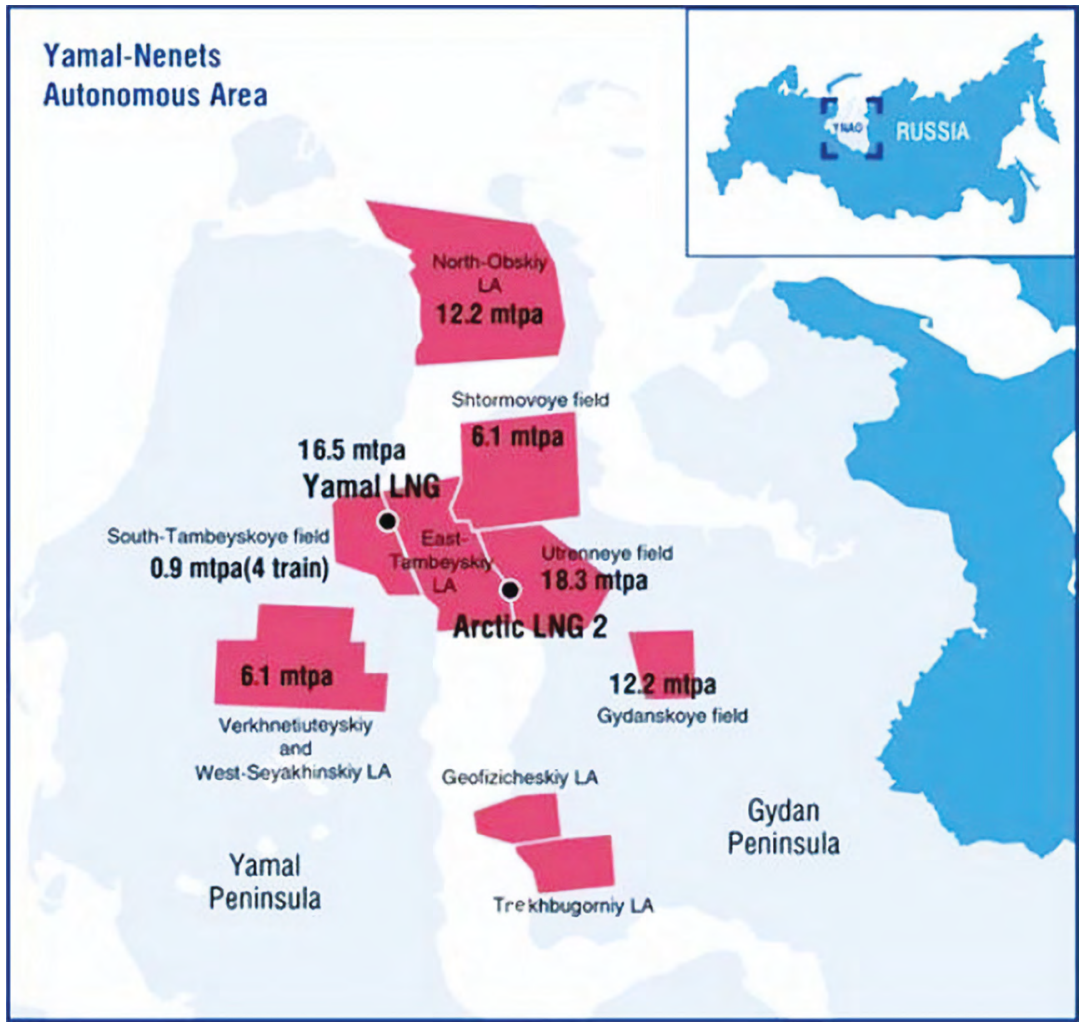

Figure 5.7: Novatek's Yamal and Gydan peninsulas' gas reserves.

Note: Yamal LNG: $16.5 \mathrm{mt}+0.9 \mathrm{mt}=17.4 \mathrm{mt} / \mathrm{y}$; Gydan LNG: $18.3 \mathrm{mt}+12.2 \mathrm{mt}+$ $12.2 \mathrm{mt}+6.1 \mathrm{mt}+6.1 \mathrm{mt}=54.9 \mathrm{mt} / \mathrm{y}$.

Source: 'Transforming into a Global Gas Company', Novatek, Strategy Presentation, released 12 December 2017, www.novatek.ru/en/investors/strategy/.

In December 2017, Novatek released its ambitious 2030 plan, which envisages the potential capacity of LNG production in the Gydan Peninsula alone will reach $55 \mathrm{mt} / \mathrm{y}$ by 2030. In April 2019, Argus projected that Novatek's LNG capacity in Russia's Arctic region could reach $43.3 \mathrm{mt}$ by around 2026, of which $17.4 \mathrm{mt} / \mathrm{y}$ would come from Yamal, $19.8 \mathrm{mt} / \mathrm{y}$ from Arctic 2 and $6.1 \mathrm{mt} / \mathrm{y}$ from Ob LNG. If a possible $1.8 \mathrm{mt} / \mathrm{y}$ from Novatek's Cryogas-Vysotsk LNG on the Baltic Sea is added, the total capacity would reach $45.1 \mathrm{mt} / \mathrm{y}$. However, considering that Novatek's initial 2030 target was $57 \mathrm{mt} / \mathrm{y}$, this still leaves a gap of 
$11.9 \mathrm{mt} / \mathrm{y}$ : clearly another large LNG project is needed. ${ }^{44}$ In June 2019, Novatek released a revised plan, Expanding Our Global LNG Footprint, from 2018 to 2030: Energy Affordability, Security \& Sustainability, which stipulated that the firm's LNG production capacity in 2024-25 would be $39 \mathrm{mt} / \mathrm{y}$, and that this figure would increase to $57-70 \mathrm{mt} / \mathrm{y}$ in $2025-30 .{ }^{45}$

Table 5.5: LNG cost breakdown by origin and destination (US\$/mmbtu)

\begin{tabular}{|l|r|r|r|r|}
\hline & US & Australia & Yamal LNG & Arctic LNG 2 \\
\hline Extraction & 3 & 3.8 & 0.8 & 0.8 \\
\hline Liquefaction & 2.5 & 4.9 & 4.1 & 2.5 \\
\hline Transport to Europe & 0.9 & 2.1 & 1.1 & 1.1 \\
\hline Transport to Asia & 2 & 0.7 & 2.8 & 2.8 \\
\hline Total to Europe & 6.4 & 10.8 & 6 & 4.4 \\
\hline Total to Asia & 7.5 & 9.4 & 7.7 & 6.1 \\
\hline
\end{tabular}

Source: 'Arctic LNG 2 to be 23\% More Competitive than US LNG in Supplies to AsiaNovatek', Interfax, 5 September 2018.

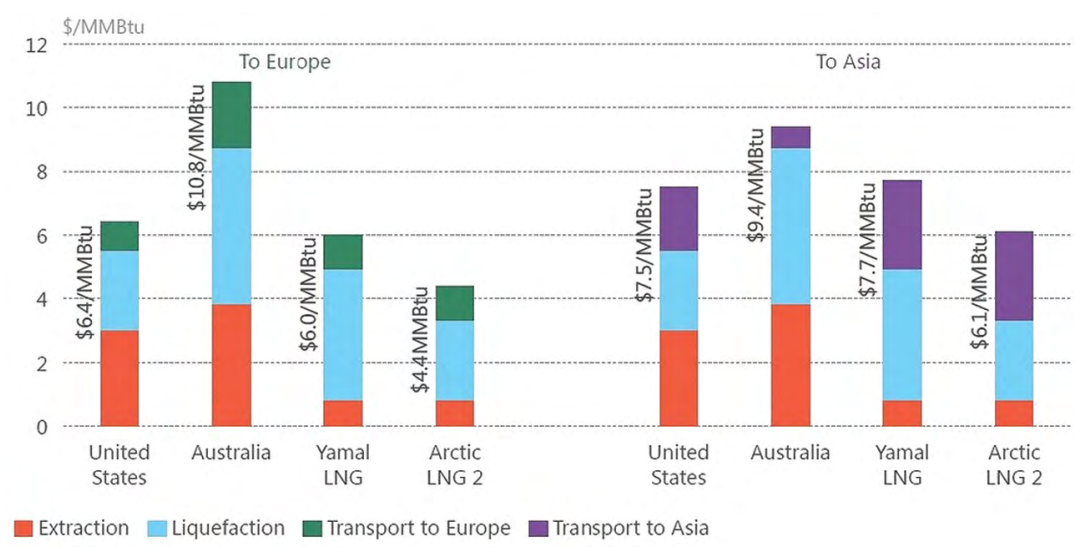

Figure 5.8: LNG cost breakdown by origin and destination.

Source: Interfax Natural Gas Daily, 7 September 2018, 4.

44 'Novatek Plans New Yamal LNG Plant', Argus FSU Energy, 18 April 2019, 5; Atle Staalesen, 'Novatek Makes Big Discovery in Gulf of Ob', Barents Observer, 11 October 2018, thebarentsobserver. com/en/industry-and-energy/2018/10/novatek-makes-big-discovery-gulf-ob; Atle Staalesen, 'Novatek Announces 3rd LNG Project in Arctic', Barents Observer, 23 May 2019, thebarentsobserver.com/en/ industry-and-energy/2019/05/novatek-announces-3rd-lng-project-arctic.

45 'Transforming into a Global Gas Company', Novatek, Strategy Presentation, released 12 December 2017, www.novatek.ru/en/investors/strategy/; Mark Gyetvay, 'Expanding Our Global LNG Footprint from 2018 to 2030: Energy Affordability, Security \& Sustainability', Novatek, Presentations, 3 June 2019, www.novatek.ru/en/investors/presentations/. 
On 27 February 2019, during the IP Week Conference in London, Novatek $\mathrm{CFO}$ and Deputy Chairman Mark Gyetvay stated that Novatek was able to deliver LNG to Europe for US\$3.15mmbtu compared to US\$7-8 mmbtu for US producers. He added that Novatek was extracting gas at a cost of US $\$ 0.1 \mathrm{mmbtu}$ versus US $\$ 3 \mathrm{mmbtu}$ in the US, and liquefying gas for US $\$ 0.5$ versus US $\$ 3$ in America. ${ }^{46}$ But this figure was not reported by the media. Gyetvay concluded that the firm could deliver LNG to Asia for US\$3.6 mmbtu, a shockingly low figure. The liquefaction figure shown in Table 5.5 does not support this figure, even though it confirms Russia’s LNG price competitiveness. Time will tell whether Novatek can prove they have the capacity to produce LNG with such a low cost. If it succeeds, it will be the game changer in the 2020s.

Table 5.6: LNG project competitiveness in US\$/mmbtu, high-income market test-Japan, Korea, Taiwan or China (JKC) 2025 (US\$/mmbtu)

\begin{tabular}{|l|r|r|r|r|}
\hline & Gas Supply & Liquefaction & Shipping & Total \\
\hline Qatar & 2.00 & 1.69 & 1.10 & 4.79 \\
\hline Russia & 0.50 & 4.52 & 0.49 & 5.51 \\
\hline Nigeria & 2.63 & 1.88 & 2.44 & 6.95 \\
\hline US GOM (New) & 2.25 & 2.25 & 2.55 & 7.05 \\
\hline Western Canada & 2.54 & 3.50 & 1.13 & 7.17 \\
\hline Mozambique & 2.54 & 3.79 & 1.53 & 7.86 \\
\hline US GOM (Existing) & 3.52 & 3.10 & 2.55 & 9.17 \\
\hline
\end{tabular}

Source: Claudio Steuer, 'Outlook for Competitive LNG Supply', Petroleum Review, July 2019, 21.

The successful implementation of Arctic LNG 2 will guarantee Russias transformation into the game changer of global LNG supply in the 2020s. During the first half of 2019, Novatek made a number of important announcements, and the preparation work for FID (financial institutions duty) on Arctic LNG 2 was completed. The first announcement occurred on 5 March 2019, when Total SA, a French oil and gas company, signed a purchase and sales agreement for a 10 per cent equity stake in Arctic LNG 2. Total SA issued the letter of intent at the 22nd Saint Petersburg International Economic Forum in May 2018. The following year, during the 23rd Saint Petersburg International Economic Forum, Novatek

46 Dmitry Zhdammikov, 'Novatek, Shell See Russian Gas Keeping Edge in Europe Over US', Reuters, 28 February 2019, www.reuters.com/article/us-russia-novatek-sanctions/novatek-shell-seerussian-gas-keeping-edge-in-europe-over-us-idUSKCN1QG21K. 
announced that it had sold a 20 per cent stake in its Arctic LNG 2 project to two Chinese companies, CNPC's upstream arm CNODC and China's biggest LNG buyer CNOOC, on the same terms as Total SA. ${ }^{47}$

In March 2019, after talks with Saudi Arabia’s Energy Minister Khalid al-Falih, Novatek CEO Mikhelson reconfirmed that the firm was prepared to consider selling a stake of up to 30 per cent in the Arctic LNG 2 project to Saudi Aramco if it was offered good terms. The deal with CNPC and CNOOC was clear confirmation that Novatek would brook no delaying tactics. As for the payment structure, Mikhelson added that:

Around 40 per cent -45 per cent is the first payment, and over 12 months the next payment to Novatek. Plus, there is the relatively large share the partners will be contributing to the Arctic LNG 2 charter capital. ${ }^{48}$

A third announcement occurred on 29 June 2019 when Novatek signed a deal with Mitsui \& Co. and Japan Oil, Gas and Metals National Corporation (JOGMEC) for 10 per cent equity sales in the Arctic LNG 2 project. The deal will supply $2 \mathrm{mt} / \mathrm{y}$ of LNG to Japan-about one-tenth of total capacity. ${ }^{49}$ It is clear that Russia wants closer cooperation with Japan and China in developing natural gas reserves; at the same time, establishing more buyers in Asia will help insulate its companies against additional Western sanctions. Japan's acquisition of the remaining 10 per cent equity not only opened the door for Novatek's FID before the end of 2019, but also makes it likely that Arctic LNG 2 will achieve its 2023 production schedule deadline.

Considering that both Saudi Aramco and South Korea failed to take part in the Arctic LNG 2 project, and Novatek has increased the 2030 target production capacity from $57 \mathrm{mt} / \mathrm{y}$ to $70 \mathrm{mt} / \mathrm{y}$, an accelerated second Arctic LNG 2 (with $19.8 \mathrm{mt} / \mathrm{y}$ ) looks increasingly likely. ${ }^{50} \mathrm{It}$ is no longer Novatek's

47 'NOVATEK and TOTAL Sign Sale Agreement for Arctic LNG 2 Stake', Novatek, 5 March 2019, www.novatek.ru/en/press/releases/index.php?id_4=3058; 'Novatek Sells Stake in Arctic LNG to Chinese Firms on Same Terms as Total Deal', Reuters, 26 April 2019, uk.reuters.com/article/usrussia-gas-novatek/novatek-sells-stake-in-arctic-lng-to-chinese-firms-on-same-terms-as-total-dealidUKKCN1S21G8.

48 'Novatek Expects Binding Agreement with Fourth Partner in Arctic LNG 2 to be Signed in H1', Interfax Russia \& CIS Oil and Gas Weekly, 6-11 June 2019, 13-15.

49 Tomoyo Ogawa, 'Russia Looks for Asia LNG Buyers to Blunt Western Sanctions' Bite', Nikkei Asian Review, 14 July 2019, asia.nikkei.com/Business/Energy/Russia-looks-for-Asia-LNG-buyers-toblunt-Western-sanctions-bite2.

50 'Novatek to Revise LNG Production Strategy Soon, Raise Target from 57 Mln to 70 Mln Tonnes by 2030-Mikhelson', Interfax Russia \& CIS Oil and Gas Weekly, 21-27 February 2019, 18-19. 
initiative alone, as the Russian state is fully supportive. In early March 2019, Interfax reported that Putin had ordered Russian Energy Minister A. Novak to study a number of proposals from Vladimir Litvinenko, rector of Saint Petersburg Mining University, concerning the development of the Russian LNG sector. According to Litvinenko, the unique geographical positions of the Yamal and Gydan peninsulas with respect to the Atlantic and Pacific sales markets, Russia's no less unique gas resource base and expertise, and the accumulated competencies of Novatek, allowed for a confident scaling of LNG production up to $140 \mathrm{or} 150 \mathrm{mt} / \mathrm{y} .{ }^{51}$ In light of this, Novak claimed at the International Arctic Forum in Saint Petersburg on 9 April 2019 that Russian LNG production could reach $73 \mathrm{mt} / \mathrm{y}$ by 2025, and 100 to 120 $\mathrm{mt} / \mathrm{y}$ by $2035 .{ }^{52}$ Russia's aim is to become one of the four major global LNG suppliers in the coming decades.

There are two factors Russia must consider if it wishes to expand its LNG operations on the Gydan Peninsula. The first is the availability of financing and the second is the timely provision of competitively priced icebreaking tankers. Saudi Arabia had been exploring the possibility of participating in Novatek's Arctic LNG 2 project since December 2017; it was considering taking a 30 per cent equity stake in the project. ${ }^{53}$ However, in April 2019, Chinese NOCs-CNODC under CNPC and CNOOC-took 20 per cent, ${ }^{54}$ and then, in June (during the G20 meeting in Osaka), Mitsui \& Co. and JOGMEC took up the remaining 10 per cent equity in the project. ${ }^{55}$ Subsequently, Saudi Arabia's offer to purchase 30 per cent equity in the Arctic project with an investment of US\$5 billion was vetoed by Novatek, which saw no reason to continue to provide a substantial discount to encourage Saudi Arabia’s entry.

It is worth noting that, instead of prioritising the Arctic LNG 2 deal, Saudi Arabia shopped around. In mid-July 2019, Interfax reported that Saudi Aramco had expressed interest in other liquefied gas projects in Russia, including Baltic LNG with Gazprom and Far Eastern LNG with

51 'Putin Orders Energy Ministry to Study Idea of Arctic National Project with Production of up to 150 Mln Tonnes of LNG a Year-Source', Interfax Russia \& CIS Oil and Gas Weekly, 28 February - 6 March 2019, 7-8.

52 'Moscow Steps Up LNG Ambitions', Petroleum Argus, 12 April 2019, 10.

53 Soldatkin and Kobzeva, 'Russia Offers to Sell Gas'.

54 Nastassia Astrasheuskaya, 'Russia's Novatek to Sell Stake in Arctic Gas Project to Chinese Partners', Financial Times, 25 April 2019.

55 Dina Khrennikova and Ilya Arkhipov, 'Mitsui, Jogmec to Invest \$3 Billion in Novatek's Arctic LNG Plant', Bloomberg, 29 June 2019, www.bloomberg.com/news/articles/2019-06-29/mitsuijogmec-to-invest-3-billion-in-novatek-s-arctic-lng-2. 
Rosneft. ${ }^{56}$ Saudi Arabia was attempting to use these LNG supply options as bargaining chips against Novatek, but the tactic backfired. Saudi Arabia will doubtless explore all options before the second Arctic LNG 2 project commences development in the early 2020s. No doubt, financing from Saudi Arabia and China will be necessary for the rapid expansion of Russia’s Arctic onshore gas-based LNG exports in the 2020s and 2030s.

Another important factor is the construction of an icebreaking fleet. In 2014, Russia's state-owned shipping company Sovcomflot placed its first order for a US\$316 million LNG carrier. South Korean shipbuilder Daewoo Shipbuilding \& Marine Engineering Co. Ltd (DSME) was commissioned to construct an ice-class tanker, known as Arc7, the first of its kind in the industry. This vessel kicked-off a US\$5 billion new-build program, which will see 15 icebreaking LNG carriers built (Table 5.7). ${ }^{57}$

As shown in Table 5.7, the first carrier's delivery was made in November 2016 and a total of 11 carriers were in operation as of May 2019. According to China Daily, the first direct shipment of LNG from Russia's Arctic region was delivered to PetroChina's Rudong terminal in Jiangsu province on 19 July 2018..$^{58}$ The second LNG tanker bound for Asia, Eduard Toll, which departed on 27 June 2018, arrived at CNPC's Rudong LNG terminal on 7 July. It is worth noting that, on 13 November 2018, Novatek Gas \& Power Asia Pte. Ltd, a subsidiary of Novatek, delivered the first shipment of LNG to CNOOC. ${ }^{59}$ In 2018, a total of four tankers were sent eastwards. On 29 June 2019, the Vladimir Rusanov, an Arc7-classed LNG tanker, left the port of Sabetta and, by 5 July, was in the Chukchi Sea close to the Bering Strait, according to Refinitiv Eikon shipping data. This marked the first voyage of the 2019 summer season across the Northern Sea Route (NSR). In 2018, four such tankers were sent eastwards. ${ }^{60}$ The Rusanov transited the ice-covered part of the route in just six days, setting

56 'Saudi Aramco Interested in LNG Projects in Russia, Including Baltic LNG with Gazprom, Far Eastern LNG with Rosneft', Interfax Russia \& CIS Oil and Gas Weekly, 11-17 July 2019, 4.

57 'DSME to Build 1st ARC7 Ice-Class Tanker for Yamal', Offshore Energy, 17 March 2014, worldmaritimenews.com/archives/106699/dsme-to-build-1 st-arc7-ice-class-tanker-for-yamal/; 'DSME Launches World's First Icebreaking LNG Carrier', Maritime Executive, 18 January 2016, www.maritime-executive.com/article/dsme-launches-worlds-first-icebreaking-lng-carrier.

58 'LNG from Arctic Reaches Jiangsu', China Daily, 20 July 2018, www.ecns.cn/business/201807-20/detail-ifywhfmh2714619.shtml.

59 'NOVATEK Shipped First LNG Cargo to CNOOC', Novatek, 13 November 2018, www. novatek.ru/en/press/releases/index.php?id_4=2804.

60 Sabina Zawadzki, 'Arctic Sea Route Opens for the Summer with First Yamal LNG Cargo', Reuters, 5 July 2019, www.reuters.com/article/russia-arctic-lng/arctic-sea-route-opens-for-the-summer-withfirst-yamal-lng-cargo-idUSL8N246304. 
a new record for independent passage via the NSR without icebreaking support and with cargo on board. The net voyage time from Sabetta to the destination port (Tianjin) in China was completed in a record 16 days. ${ }^{61}$ Separately, on 26 June 2019, Novatek announced that Yamal LNG had shipped the first cargo of LNG to Japan in accordance with the long-term offtake agreement with Total SA. The cargo was unloaded at the Tobata LNG terminal. ${ }^{62}$

\section{Table 5.7: List of 15 icebreaking LNG carriers}

\begin{tabular}{|l|l|l|}
\hline Vessel name & Stage & $\begin{array}{l}\text { Operator/Commencement } \\
\text { of operation }\end{array}$ \\
\hline Chris. de Margerie & In operation & Sovcomflot/November 2016 \\
\hline Boris Vilkitsky & In operation & Dynagas/November 2017 \\
\hline Fyodor Litke & In operation & Dynagas/November 2017 \\
\hline Eduard Toll & In operation & Teekay/CLNG/December 2017 \\
\hline Vladimir Rusanov & In operation & MOL/CSLNG/January 2018 \\
\hline Rudolf Samoylovich & In operation & Teekay/CLNG/August 2018 \\
\hline Vladimir Vize & In operation & MOL/CSLNG/October 2018 \\
\hline Georgiy Brusilov & In operation & Dynagas/December 2018 \\
\hline Boris Davydov (DSME 2428) & In operation & Dynagas/January 2019 \\
\hline Nikolay Zubkov (DSME 2429) & In operation & Dynagas/February 2019 \\
\hline Nikolay Evgenov (DSME 2430) & In operation & Teekay/CLNG/May 2019 \\
\hline Vladimir Voronin (DSME 2431) & Sea trials & Teekay \\
\hline Nikolay Urvantsev (DSME 2432) & Sea trials & MOL \\
\hline Georgiy Ushakov (DSME 2433) & Due 29 January 2020 & Teekay \\
\hline Yakov Gakkel (DSME 2434) & Wet dock & Teekay \\
\hline
\end{tabular}

Note: $C L N G$ = China LNG Shipping; $M O L=$ Mitsui OSK Lines; CSLNG = China COSCO Shipping.

Source: Mark Gyetvay, 'Expanding Our Global LNG Footprint from 2018 to 2030: Energy Affordability, Security \& Sustainability', Novatek, Presentations, 3 June 2019, www.novatek.ru/ en/investors/presentations/; Sabina Zawadzki, 'Two Arc7 Arctic LNG Tankers Start Sea Trials to Join Yamal Fleet', Reuters, 18 June 2019, www.reuters.com/article/lng-yamal-shipping/ table-two-arc7-arctic-lng-tankers-start-sea-trials-to-join-yamal-fleet-idUSL8N23P141; 'IceBreaking LNG Carrier for Yamal LNG Project Named Vladimir Vize', MOL, 12 September 2018, www.mol.co.jp/en/pr/2018/18060.html; 'Christophe de Margerie Class Icebreaking LNG Carriers', Ship Technology, accessed 22 August 2020, www.ship-technology.com/ projects/christophe-de-margerie-class-icebreaking-Ing-carriers/.

61 'LNG Carrier "Vladimir Rusanov" Opens the Northern Sea Route 2019 Navigation Period', Port News, 25 July 2019, en.portnews.ru/news/280799/.

62 'Yamal LNG Shipped First LNG Cargo to Japan', Novatke, 26 June 2019, www.novatek.ru/en/ press/releases/index.php?id_4=3268\&from_4=2. 


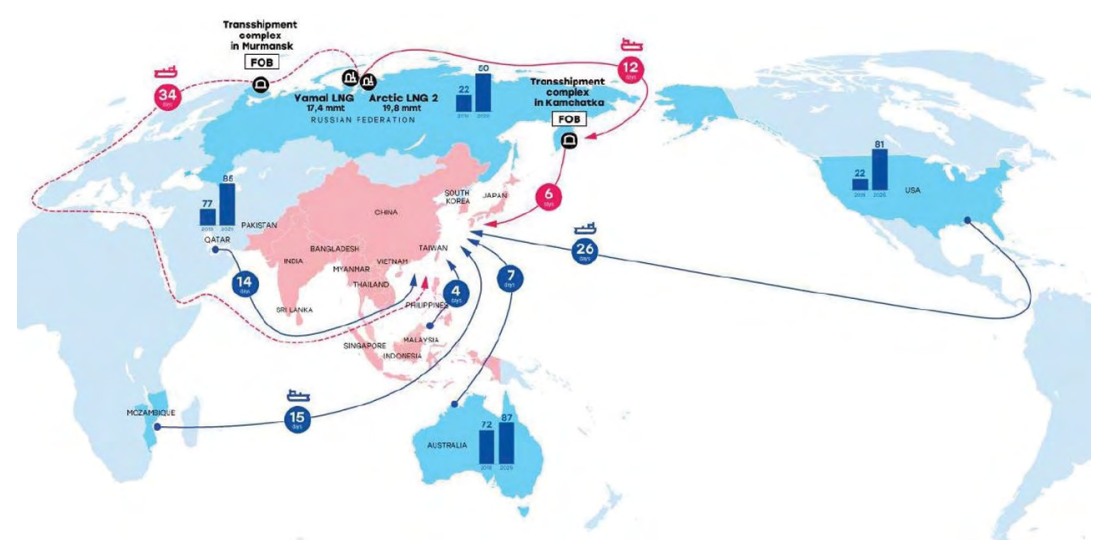

\section{Figure 5.9: Novatek's LNG logistics to Asia.}

Source: Mark Gyetvay, Expanding Our Global LNG Footprint from 2018 to 2030: Energy Affordability, Security \& Sustainability (Novatek, 2019).

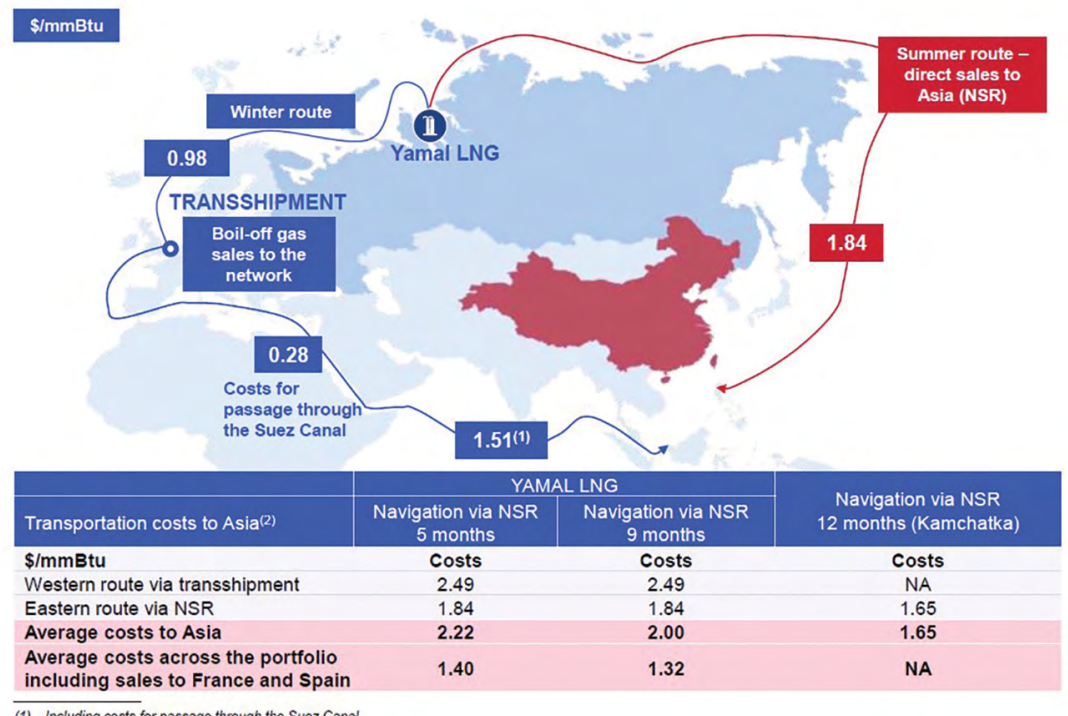

(1) Including costs for passage through the Suez Canal

\section{Figure 5.10: LNG transportation costs: East versus West routes.}

Source: 'Transforming into a Global Gas Company: From 2018 to 2030'. Novatek, 12 December 2017. 
In an effort to overcome a potential shortage of LNG carriers and other logistical challenges, Novatek partnered with Sovcomflot (Russia's largest shipping company) in ordering four new Arc7 LNG carriers, and contracted TechnipFMC, a UK-based company that provides complete project life cycle services, to engineer, procure, supply, construct and commission Arctic LNG 2's new facility on the Gydan Peninsula. ${ }^{63}$

Experts calculate that Novatek will require another 5 to 10 Arc 7 carriers in addition to its existing fleet of 15 carriers. ${ }^{64}$ Mikhail Grigoriev of Arctic consultancy Gecon explained that this would allow it to maintain a continuous flow of LNG to Europe and Asia. Experts caution that only the $120 \mathrm{MW}$ Leader Class nuclear icebreaker, which is more than twice as powerful as any other nuclear icebreaker, will be capable of keeping the route open. That icebreaker, however, has yet to progress past initial discussion stages and would not be available until 2027 at the earliest. ${ }^{65}$
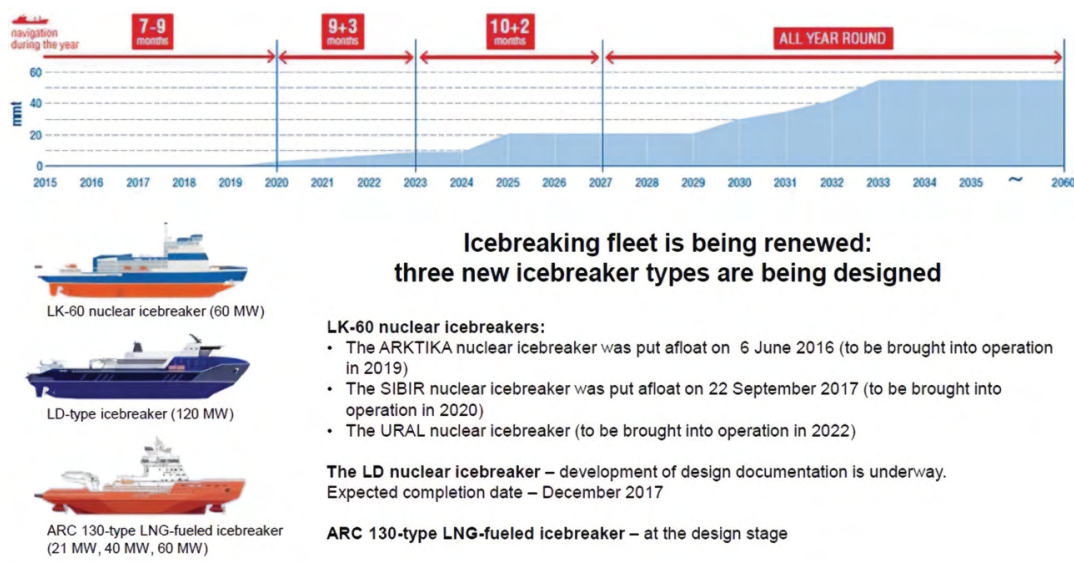

Icebreaking fleet is being renewed: three new icebreaker types are being designed

LK.60 nuclear icebreakers:

- The ARKTIKA nuclear icebreaker was put afloat on 6 June 2016 (to be brought into operation in 2019)

- The SIBIR nuclear icebreaker was put afloat on 22 September 2017 (to be brought into operation in 2020)

- The URAL nuclear icebreaker (to be brought into operation in 2022)

The LD nuclear icebreaker - development of design documentation is underway. Expected completion date - December 2017

ARC 130-type LNG-fueled icebreaker - at the design stage

\section{Figure 5.11: LNG transit via Northern Sea Route subject to icebreakers commissioning.}

Source: Mark Gyetvay, 'Expanding Our Global LNG Footprint from 2018 to 2030: Energy Affordability, Security \& Sustainability', Novatek, Presentations, 3 June 2019, www.novatek.ru/en/investors/presentations/.

63 Malte Humpert, 'Novatek Signs Contract for Construction of Arctic LNG 2, Orders New LNG Carriers', High North News, 21 May 2019, www.highnorthnews.com/en/novatek-signscontract-construction-arctic-lng-2-orders-new-lng-carriers; 'Novatek's Yamal LNG to Face Logistical Challenges during Winter Months', High North News, 5 October 2018, www.highnorthnews.com/ en/novateks-yamal-lng-face-logistical-challenges-during-winter-months.

64 'Novatek Allowed to Operate Foreign LNG Carriers on Northern Sea Route', High North News, 21 March 2019, www.highnorthnews.com/en/natural-gas-company-novatek-was-granted-exemptionnew-law-banning-foreign-flagged-oil-and-gas.

65 'Novatek Allowed to Operate Foreign LNG Carriers on Northern Sea Route'. 
Novatek is confident that it can shift the majority of its LNG exports from Europe to Asia by 2023. Mikhelson stated:

If Atomflot provides us with a speed of seven to eight knots, we have no doubt that we will make a transit point on Kamchatka by 2022. We are very clearly oriented that $80-85$ per cent [of LNG], no matter what they say, will be delivered to the East. ${ }^{66}$

While the original 15 carriers were constructed by South Korea's DSME, the Russian Government aims to construct subsequent vessels at the Zvezda shipbuilding complex in the Russian Far East, in cooperation with DSME. ${ }^{67}$ In April 2019, Sovcomflot placed an order for an additional Arc7 carrier to be built by Zvezda by 2023, to coincide with the opening of Arctic LNG 2. On 21 May, Novatek, Sovcomflot and Zvezda agreed on the construction of an additional four vessels, at a unit cost of US $\$ 375$ million for delivery by 2025 . This order would potentially close Novatek's projected shortage of Arc7 carriers. However, unit costs are around US\$50 million or 15 per cent higher than in South Korea. ${ }^{68}$ The price difference-up to 20 per cent-will be covered through subsidies from the Russian state budget. ${ }^{69}$ The Russian Government is willing to pay the price to improve its shipbuilding capacity.

Novatek was much faster than the Russian Government in taking a pragmatic but bold stance, opening the door for China Offshore Oil Engineering Company (COOEC), a subsidiary of CNOOC, to play a major role in the Yamal LNG project. On 9 April 2016, COOEC delivered the first key module of the project to the Russian client, marking China's first export of the key LNG modules. COOEC ultimately built 36 core modules for Yamal LNG, mastering this technology

66 Humpert, 'Novatek Signs Contract'.

67 'Novatek Allowed to Operate Foreign LNG Carriers on Northern Sea Route'.

68 'Sovcomflot Moored at Arctic LNG', Kommersant, 20 May 2019, www.kommersant.ru/doc/ 3974775 .

69 'Sovcomflot Moored at Arctic LNG'; 'Zvezda Shipyard Signs Contract with Sovkomflot to Build Arctic Gas Carrier for Arctic LNG 2 Project', Port News, 10 April 2019, en.portnews.ru/news/275342/; 'Sovcomflot Approves LNG-Fueled Tanker Orders at Zvezda Shipyard', Offshore Energy, 29 July 2019, www.lngworldnews.com/sovcomflot-approves-lng-fueled-tanker-orders-at-zvezda-shipyard/; 'Zvezda Shipyard Started Serial Production of Aframax Tankers', Zvezda, 21 November 2018, www.sskzvezda. ru/index.php/en/contact/9-news-en/195-zvezda-shipyard-started-serial-production-of-aframax-tankers. 
through participation in the project. This breakthrough is in line with Beijing's plan for China to move up the chain in manufacturing ocean engineering equipment. ${ }^{70}$

In early June 2019, Novatek, together with China SOSCO Shipping Co. Ltd, Sovcomflot and the Silk Road Fund, signed an agreement in respect of the Maritime Arctic Transport LLC. ${ }^{71}$ The agreement confirms that the four parties aim to establish a long-term partnership providing for the joint development, financing and implementation of year-round logistics arrangements for shipping hydrocarbons from the Arctic Zone of the Russian Federation to the Asia-Pacific region, as well as organising transit cargo traffic along the NSR between Asia and Western Europe.

The Japanese shipbuilding company with the greatest involvement in the Yamal LNG project is Mitsui OSK Lines (MOL). MOL, in cooperation with the China Ocean Shipping Company (COSCO), aimed at taking ownership of four of the project's icebreaker tankers, with the first of these, Vladimir Rusanov, entering operation in January 2018. ${ }^{72}$ Based on their Yamal experience, it is not surprising that MOL formed an alliance with JOGMEC to purchase a 10 per cent equity stake in Arctic LNG 2.

Unlike China and Japan, South Korea failed to take part in the Arctic LNG 2 project despite the MOU between Kogas and Novatek in June $2018 .^{73}$ South Korea's somewhat naive approach to the NSR shipping business explains the difficulties Russia faces in gaining entry to the Asian gas market. Had South Korea decided to take 10 per cent equity in the Arctic LNG 2 project, it would have opened the door for DSME to build the extra icebreaking tankers needed for Arctic LNG 2 project. Diversification of LNG supply and optimal price is Korea's highest

70 'COOEC Delivers 36 Core Modules of Yamal LNG Project on Time', Euro Petrole, 21 August 2017, www.euro-petrole.com/cooec-delivers-36-core-modules-of-yamal-lng-project-on-time-n-i-15307; Xu Yihe, 'Chinese Yards Back in the Fray for Arctic LNG 2',Upstream, 8 May 2019, www.upstream online.com/hardcopy/1774834/chinese-yards-back-in-the-fray-for-arctic-lng-2; Li Yulong, Kong Linghao and Liu Jia, 'Yamal LNG Project and Made-in-China Equipment Going Globally', China Oil \& Gas, no. 3 (2016): 13-17; Zheng Xin and Zhang Min, 'Top-end Oil-gas Equipment Next', China Daily, 17 April 2017, www.chinadaily.com.cn/business/2017-04/17/content_28953838.htm; 'Milestone Is in the Pipeline', China Daily Europe, 23 April 2017.

71 'NOVATEK, COSCO SHIPPING, Sovcomflot and Silk Road Fund Sign an Agreement in Respect of Maritime Arctic Transport LLC', Novatek, 7 June 2019, www.novatek.ru/en/press/releases/ index.php?id_4=3243\&from_4=2.

72 James D. Brown, 'Japan and the Northern Sea Route', Shingetsu News, 5 March 2018, shingetsunewsagency.com/2018/03/05/japan-northern-sea-route/.

73 Choi, 'Development in Russian-Asian Energy Cooperation'. 
priority, as President Moon Jae-In's administration is determined to move away from coal and nuclear to renewable energy and gas. ${ }^{74}$ Novatek CFO Mark Gyetvay warned during an interview with JoongAng Daily ${ }^{75}$ that DSME's easy ride for the US $\$ 5$ billion worth of icebreaking LNG tankers then under construction would not be repeated if there was no financial contribution for Arctic LNG 2 from South Korea. However, all is not lost. Even though the Arctic LNG 2 project's funding procedure is closed, there is no harm in South Korea exploring the possibility of securing 5-9.9 per cent of equity by diluting Novatek's 60 per cent equity to 50.155 per cent. Novatek's expectation of participation by South Korea in its Arctic LNG projects is purposefully done.

Russia's old and ambitious dream of becoming the swing oil and gas supplier for Europe and Asia may no longer be a pipedream. As the POS 1 gas started to flow at the end of 2019, Russia witnessed the first tangible results of exporting piped gas to China. It remains to be seen whether and when the Altai gas or POS 2 will follow.

Russia's dominance in the European gas market has brought increased pressure to bear from the US. According to Rystad Energy, Russian gas delivered to Europe has a low break-even price of around US $\$ 5$ per mmbtu. This compares to a long-run marginal cost of between $\$ 6.00$ and $\$ 7.70 \mathrm{mmbtu}$ for US LNG. ${ }^{76}$ The hard line US stance towards Russia is very likely to trigger Gazprom's compromise on the Altai gas deal. Ironically, the US's strategy of using Qatar LNG to balance Russia's dominance in Europe's gas market could unintentionally help Russia's ambition of becoming a swing gas supplier. In September 2018, Qatar said it would invest $€ 10$ billion (US\$11.6 billion) to strengthen its ties with Germany over the next five years, including the possible creation of an LNG terminal.

74 Keun-Wook Paik, 'South Korea's Energy Policy Change and the Implications for its LNG Imports', OIES Paper, 27 June 2018, www.oxfordenergy.org/wpcms/wp-content/uploads/2018/06/ South-Koreas-Energy-Policy-Change-and-the-Implications-for-its-LNG-Imports-NG132.pdf.

75 Author assisted with this interview in October 2017 and the article was published in early December 2017. See, Kim Sang-jin, 'First Export of LNG from Arctic ... The Global LNG Market Is Also Changing', MNNews, accessed 22 August 2020, mnews.joins.com/article/22184683?cloc= joongang\#home.

76 'Could LNG from the US Pose a Short-Term Challenge to Russian Gas in Europe?', Rystad Energy, 5 February 2019, www.rystadenergy.com/newsevents/news/press-releases/Could-LNG-fromthe-US-pose-a-short-term-challenge-to-Russian-gas-in-Europe/. 
In January 2019, Deputy US Energy Secretary Dan Brouillette, speaking in Doha, confirmed that the US was talking with Doha about supplying Europe with LNG, as it wanted Germany and other countries to import Qatari and US gas rather than Russian gas, which accounted for 60 per cent of German gas imports. Brouillette said he had discussed the issue with Qatar's Minister of State for Energy Affairs Saad al-Kaabi, who was also chief executive of Qatar Petroleum (QP)—majority owner of the Golden Pass LNG terminal, with Exxon Mobil and ConocoPhillips holding smaller stakes. Brouillette added that Qatari investments in the Golden Pass, and in US export facilities, enabled the US to get natural gas to Europe. He acknowledged that LNG would cost more than piped gas but said that LNG supplies from Qatar and other countries would help diversify supply sources to Europe. ${ }^{77}$ Qatar's LNG cooperation with the US has been carefully managed to ease the pressure of a blockade by its regional neighbours, Saudi Arabia, Arab Emirates (UAE), Bahrain and Egypt, since 2017..$^{7}$ In this context, it is understandable why Russia is so keen on Saudi Arabia's participation in the Gydan Peninsula's LNG development scheme. Russia's desire to make Saudi Arabia its strategic partner and LNG buyer is a direct response to Qatar's alliance with the US.

Wood Mackenzie projected that LNG imports to Japan would fall by 12 per cent to $72.8 \mathrm{mt} / \mathrm{y}$ by 2022 , while China's import volumes would rise by 37.5 per cent to $74.1 \mathrm{mt} / \mathrm{y}$. The firm added that Japanese imports would remain above $70 \mathrm{mt} / \mathrm{y}$ through much of the 2020 s, while LNG demand was declining. The country would remain the second-largest LNG consumer in the world until at least 2040, with demand exceeding $60 \mathrm{mt} / \mathrm{y}^{79}$ It took only two decades for China to become the biggest LNG importer, and it looks very likely that China will become the price setter of global LNG supply. The expansion of LNG in China will be fundamentally affected by the supply of pipeline gas to China.

77 Rania El Gamaland Eric Knecht, 'US Wants Qatar to Challenge Russian Gas in Europe-US Official', Reuters, 14 January 2019, www.reuters.com/article/usa-energy-gulf-idUSL8N1ZE1XG.

78 Linah Alsaafin, 'Qatar Has Moved on Two Years Since Blockade, Analysts Say', Aljazeera, 5 June 2019, www.aljazeera.com/news/2019/06/qatar-moved-years-blockade-analysts-190604215831200. html.

79 David Rowlands, 'Wood Mackenzie: China Could Overtake Japan as Top LNG Importer by 2022', LNG Industry, 23 July 2019, www-Ingindustry-com.cdn.ampproject.org/c/s/www.lngindustry. com/regasification/23072019/wood-mackenzie-china-could-overtake-japan-as-top-lng-importerby-2022/amp/. 
CNOOC has warned that China's LNG imports will grow much more slower than its piped imports during 2019-30. CNOOC VP Li Hui said at the LNG 2019 conference that China is expected to import $57 \mathrm{bcm}$ of pipeline gas in 2019 and $63 \mathrm{bcm}$ in 2020 . The figure will be $121.8 \mathrm{bcm}$ by 2025 and $126 \mathrm{bcm}$ in 2030, representing a 121 per cent increase from 2019. In the meantime, China's LNG imports will reach $60 \mathrm{mt}$ in 2019equivalent to $84 \mathrm{bcm}$ after regasification-and then rise to $70.7 \mathrm{mt}$ in 2020. CNOOC expects imports to rise slowly in the second half of the 2020 s, reaching $83 \mathrm{mt}(116.2 \mathrm{bcm})$ in 2025 and $88.6 \mathrm{mt}(124 \mathrm{bcm})$ in 2030. This would equate to a growth of 48 per cent between 2019 and 2030. CNPC ETRI has predicted that pipeline imports will hit $65 \mathrm{bcm}$ in 2020 and will double to $130 \mathrm{bcm}$ by $2030 .^{80}$

China's leaders' preference for pipeline gas is well known and this will definitely be strengthened if the Hormuz Strait crisis and South China Sea's territorial disputes are intensified. An executive from PetroChina said at LNG 2019 that China's LNG imports could hit $110 \mathrm{bcm}$, equivalent to $80 \mathrm{mt} / \mathrm{y}$, by 2025 . CNPC's projection of $130 \mathrm{bcm} / \mathrm{y}$ by 2030 indicates that China may not take both Altai gas and Central Asian D Line gas. In other words, only one, either Altai or D Line, will be chosen. ${ }^{81}$ If Altai gas instead of D Line is chosen, it will transform Russia into an effective swing gas supplier between the European and Asian markets in the coming decades. Russia's long-term dream of becoming a swing supplier of both oil and gas between the European and Asian markets will then be a reality. Although a blessing for Russia, this would be a nightmare for both Western Europe and the US.

In short, the coming decade will witness no slowdown of ESPO crude supply to the Asian oil market and increasing supplies of both pipeline gas and LNG. Sino-Russian oil and gas cooperation will play the pivotal role in opening the era of Russia’s Asia-Pacific policy.

80 Shek and Tian, 'China’s Piped Imports'.

81 Shek and Tian, 'China's Piped Imports'. 
This text is taken from Russian Energy Strategy in the Asia-Pacific: Implications for Australia, edited by Elizabeth Buchanan, published 2021 by ANU Press, The Australian National University, Canberra, Australia.

doi.org/10.22459/RESAP.2021.05 